\title{
Bibliography on the Biology and Pharmacology of Lithium. 9
}

\author{
M. $\quad$ Mogens $\quad$ Schou
}

The Psychopharmacology Research Unit, Aarhus University Institute of Psychiatry, Psychiatric Hospital, Risskov, Denmark

This bibliography is the ninth in a series; it will also be the last. Electronic information storage and retrieval systems have developed so rapidly during recent years that traditional topical bibliographies must be considered outdated. References to publications about the biology and pharmacology of lithium can now be found readily through the general library data bases. Attention is directed to the computerized Lithium Information Center, Department of Psychiatry, University of Wisconsin, 600 Highland Avenue, Madison, WI 53792, to which questions may be addressed by letter or by telephone (608)263-6171. Drs. /. W. Jefferson, J.H. Greist and M. Baudhuin are in charge of the center. Authors publishing about lithium would do well in submitting reprints or full bibliographic information to the center.

The eight previous bibliographies appeared in: (1) Psychopharmacology Bulletin 5: No. 4, 33-62 (1969); (2) Psychopharmacology Bulletin 8: No. 4, 36-62 (1972); (3) Psychopharmacology Bulletin 12: No. 1, 49-74, No. 2, 69-83, No. 3, 86-99 (1976); (A) Neuropsychobiology 2: 161-191 (1976);

${ }^{1}$ Reprints will not be available.

\{5) Neuropsychobiology 4: 40-64 (1978): \{6) Neuropsychobiology 5: 241-265 (1979); \{1) Neuropsychobiology 6: 1-28 (1980), and (8) Neuropsychobiology 7: 26-55 (1981). The present bibliography follows the same lines as its predecessors. Lithium Corporation of America gave financial support.

The last year has seen relatively few major reviews. Švestka [1979] reviewed points of therapy and prophylaxis in psychiatry. Ehr-lich and Diamond [1980] dealt with lithium, membranes, and manic-depressive illness. The papers from a conference on 'Lithium effects on granulopoiesis and immune function' were published by Rossofand Robinson [1980]. References to studies in which lithium was used merely as an aversive agent in conditioning experiments have usually not been included here. Such studies may, however, also contain observations of more general interest; they are reviewed by Smith [1977, 1981].

A small guidebook about lithium treatment, written for the information and instruction of patients, relatives, and health personnel, has appeared in English, German, Swedish and Danish [Schou, 1980, 1980, 1981, 1978].

Bibliography on the Biology and Pharmacology of Lithium. 9

255

\section{References}

Abbondanza, A.: Effect of lithium chloride on cerebral GABA levels in rats after single or repeated doses of ethanol. J. Stud. Alcohol 41: 347-351 (1980).

Abrams, A. A.; Braff, D.L.: Lithium-induced cogwheel rigidity: treatment with amantadine. Pharmako-psychiatr. Neuro-Psychopharmakol. 13: 240-242 (1980)

Abrams, R.; Taylor, M.A.: A comparison of unipolar and bipolar depressive illness. Am. J. Psychiat. 137: 1084-1087 (1980).

Adams, D.J.; Dwyer, T.M.; Hille, B.: The permeability of endplate channels to monovalent and divalent metal cations. J. gen. Physiol. 75: $493-510$ (1980).

Adebimpe, V.R.: Psychopharmacologic norms in blacks and whites. Am. J. Psychiat. 137: 870-871 (1980)

Adebimpe, V.R.: Psychopharmacologic norms in blacks and whites. Am. J. Psychiat. 137: 870-871 (1980). Ahlfors, U.G.; Amdisen, A.; Bucht, H.; Dencker, S.J.; Hansen, H.E.;

Albrecht, J.: Effekte von Lithium auf die Schilddrüse. (Effects of lithium on the thyroid gland.) Innere Med. 7:69-75 (1980).

Albrecht, J.; Kampf, D.; Müller-Oerlinghausen, B.: Renal function and biopsy in patients on lithium therapy. Pharmakopsychiatr. Neuro-Psychopharmakol. 13: 228-234 (1980).

Albrecht, J.; Müller-Oerlinghausen, B.: Kardiovasku-läre Nebenwirkungen von Lithium. (Cardiovascular side effects of lithium.) Dt. med. Wschr. 105: 651-655 (1980).

Aldoroty, N.; LeVine, W.R.: Dermatosis and lithium therapy. Am. J. Psychiat. 137: 870 (1980).

Alexander, G.J.; Lieberman, K.W.; Stokes, P.: Differential lethality of lithium isotopes in mice. Biol. Psychiat. 15: 469-471 (1980).

Allison, J.H.; Boshans, R.L.; Hallcher, L.M.; Packman, P.M.; Sherman, W.R.: The effects of lithium on myo-inositol levels in layers of frontal cerebral cortex, in cerebellum, and in corpus callosum of the rat. J. Allison, J.H.; Boshans, R.L.; Hallcher, L.M.; Packman, P.M.; Sherman, W.R.: The effects of lithium
Neurochem. 34: 456 58 (1980).

Altesman, R.I.; Cole, J.O.: Lithium therapy: a practical review. McLean Hosp. J. 3: 106-121 (1978).

Alvarez, E.; Casas-Brugue, M.; Udina Abello, C; Queralto-Compano, J.M.: Plasma and red cell lithium. Br. J. Psychiat. 136: $521-522$ (1980)

Amdisen, A.: Serum concentration and clinical supervision in monitoring of lithium treatment. Ther. Drug Monitg 2: 73-83 (1980).

Amdisen, A.: Lithium; in Evans, Schentag, Jusko, Applied pharmacokinetics, pp. 586-617 (Applied Therapeutics, San Francisco 1980).

Amdisen, A.: Serumlitiumkontrol: '12h-stSLi' (sive 'SLi (12h-st)' og dens placering i styrings- og over-vågningsproceduren. (Serum lithium control: the 12-hour serum lithium concentration and its place in treatment monitoring.) Nord. psykiat. Tidsskr. 34: 484-504 (1980).

Amdisen, A.: Lithiumdosis. (Lithium dosage.) Ugeskr. Læg. 143: 494-495 (1981).

Amdisen, A.: Lithiumdosis. (Lithium dosage.) Ugeskr. Læg. 143: 494-495
Amdisen, A.; Schou, M.: Lithium. Side Eff. Drugs Annu. 4: 22-25 (1980).

Amdisen, A.; Schou, M.: Lithium; in Dukes, Meyler's side effects of drugs; 9th ed., pp. 43-50 (Excerpta Medica, Amsterdam 1980).

Ananth, J.; Engelsmann, F.; Kiriakos, R.: Evaluation of lithium response: psychometric findings. Can. J. Psychiat. 25: 151-154(1980)

Angst, J.: Verlauf unipolar depressiver, bipolar ma-nisch-depressiver und schizo-afTektiver Erkran-kungen und Psychosen: Ergebnisse einer prospekti-ven Studie. (Course of unipolar depressive, bipolar manicdepressive, and schizo-affective disorders: results of a prospective longitudinal study.) Fortschr. Neurol. Psychiat. 48: 3-30 (1980).

Angst, J.; Felder, W.; Lohmeyer, B.: Verlauf schizo-affektiver Psychosen. (Course of schizo-affective psychoses); in Schimmelpenning, Psychiatrische Verlaufsforschung, pp. 176-194 (Huber, Bern 1978).

Angst, J.; Müller-Oerlinghausen, B.: Methodologische Anmerkungen zur Langzeitbehandlung mit Lithium. (Methodological comments on long-term treatment with lithium.) Pharmakopsychiatr. NeuroPsychopharmakol. 13: 152-155 (1980).

Anonymous: Another look at lithium. Med. Lett. 22/4: 17-19 (1980).

Anton, R.F.: Linoleic acid in the treatment of lithium toxicity and familial tremor. Prostagland. Med. 5: 321-322 (1980).

Arató, M.; Rihmer, Z.; Felszeghy, K.: Reduced plasma cyclic AMP level during prophylactic lithium treatment in patients with affective disorders. Biol. Psychiat. 75:319-322(1980).

Arora, R.C.; Meltzer, H.Y.: Lithium and serotonin uptake by platelets. Br. J. Psychiat. 137: 396-397 (1980).

256 
Arruda, J.A.L.; Dytko, G.; Mola, R.; Kurtzman, N.A.: On the mechanism of lithium-induced renal tubular acidosis: studies in the turtle bladder. Kidney int. 17: 196-204(1980)

Arruda, J.A.L.; Roseman, M.K.; Sehy, J.T.; Nasci-mento, L.; Batlle, D.; Kurtzman, N.A.: Effect of lithium administration on distal nephron function. Mineral Electrolyte Metab. 4: 81-88 (1980).

Ayd, F.J.: Lithium-haloperidol for mania: is it safe or hazardous? in Ayd, Haloperidol update: 1958 - 1980, pp. 83-92 (Ayd Medical Communication, Baltimore 1980).

Baastrup, P.C.: Guide-lines for lithium prophylaxis in recurrent affective disorders (Dumex, Copenhagen 1980).

Baastrup, P.C.; Schou, M.: This week's citation classic. Curr. Contents/Clin. Pract. 24/4: 16 (1981).

Balfour, D.; Hewick, D.; Murray, N.: Comparison of plasma, erythrocyte and brain lithium concentrations in the guinea-pig and rat. Br. J. Pharmacol. 67: 474P-^§75P (1979).

Balın, R.; Kabeš, J.; Papežová, H.; Dostal, T.: Comparison of the classical and retarded form of lithium carbonate. Activitas nerv. sup. 22: 174-175 (1980).

Bandini, G.: Lithium and granulocyte function. Lancet $i: 152$ (1981).

Bandini, G.; Rịcci, P.; Visani, G.; Tura, S.: Lithium carbonate in hæmatology. Lancet ii: 926 (1980).

Banduhn, N.; Obe, G.; Müller-Oerlinghausen, B.: Is lithium mutagenic in man? Pharmakopsychiatr. Neuro-Psychopharmakol. 13: 218-227 (1980)

Bannet, J.; Ebstein, R.P.; Belmaker, R.H.: Clinical aspects of the interaction of lithium and stimulants. Br. J. Psychiat. 136: 204 (1980).

Barrett, A.J.: Haematological effects of lithium and its use in treatment of neutropenia. Blut 40: 1-6 (1980).

Barrett, A.J.: Clinical experience with lithium in aplas-tic anemia and congenital neutropenia; in Rossof, Robinson, Lithium effects on granulopoiesis and immune function, pp. 305-320 (Plenum, New York 1980).

Barrett, A.J.; Faille, A.: Clinical studies with lithium; in Najean, Medullary aplasia, pp. 241-244 (Mas-son, New York 1980).

Bártová, D.; Náhunek, K.; Švestka, J.; Hajnová, R.: Comparative study of prophylactic lithium and diethylstilbestrol in sexual deviants. Activitas nerv. sup. 21: 163-164(1979).

Bech, P.; Shapiro, R.W.; Sihm, F.; Nielsen, B.-M.; Sørensen, B.; Rafaelsen, O.J.: Personality in unipolar and bipolar manic-melancholic patients. Acta psychiat. scand. 62: 245-257 (1980).

Becker, B.F.; Duhm, J.: Studies on lithium transport across the red cell membrane. VI. Properties of a sulfhydryl group involved in ouabain-resistant $\mathrm{Na}^{+}-\mathrm{Li}^{+}$(and $\mathrm{Na}^{+}-\mathrm{Na}^{+}$) exchange in human and bovine erythrocytes. J. Membr. Biol. 51: 287-310 (1979).

Bell, F.R.; Sly, J.: The effect of lithium intake on the sodium and lithium appetite of calves. J. Physiol., Lond. 296: 32 (1979).

Belmaker, R.H.; Ebstein, R.P.: Adenylate cyclase and the mechanism of lithium action; in Saletu, Neu-ropsychopharmacology, pp. 173-184 (Pergamon Press, Oxford 1979).

Belmaker, R.H.; Kon, M.; Ebstein, R.P.; Dasberg, FL: Partial inhibition by lithium of the epinephrine-stimulated rise in plasma cyclic GMP in humans. Biol. Psychiat. 75:3-8 (1980).

Ben-Aryeh, H.; Naon, H,; Szargel, R.; Gutman, D.; Hefner, A.: Salivary lithium concentration: a tool for monitoring psychiatric patients. Oral Surg. Med. Pathol. 50: 127-129 (1980)

Bender, W.; Siepmann, K.: Therapeutische Stereoty-pien bei psychiatrischen Erkrankungen. (Therapeutic stereotypies in psychiatric diseases.) Psy-chiatria clin. 13: 1-12 (1980).

Bennett, P.B.; Leventhal, B.L.; Coggin, R.; Roby, J.; Racanska, L.: Lithium effects: protection against nitrogen narcosis, potentiation of HPNS. Undersea biomed. Res. 7: 11-16 (1980).

Benos, D.J.; Mandel, L.J.; Simon, S.A.: Cationic selectivity and competition at the sodium entry site in frog skin. J. gen. Physiol. 76: 233-247 (1980).

Bente, D.; Kriebitz, R.; Scheuler, W.: Untersuchung zur Wïrkung einer zweiwöchigen Lithium-Appli-kation auf die hirnelektrische Wachaktivität ge-sunder Probanden während der Durchführung einer visuo-

motorischen Regelaufgabe. (Investigation of the effect of a 2-week lithium application on the cerebro-electrical activity of healthy volunteers while solving a visuo-motor task.) Arzneimittel-Forsch. 30: motorischen

Berggren, U.; Ahlenius, S.; Engel, J.: Effects of acute lithium administration on conditioned avoidance behavior and monoamine synthesis in rats. J. neural Transm. 47: 1-10(1980).

Berkestijn, J.W.B. van: Het klinische gewicht van een

Bibliography on the Biology and Pharmacology of Lithium. 9

257

licht metal. (The clinical significance of a light metal.) Ned. Tïjdschr. Geneesk. 124: 537-540 (1980).
Bernal, A. de la Rica; et al.: Toxic and side effects of lithium salts in patients under prolonged treatment. (In Spanish.) Actas luso-esp. Neurol. Psi-quiat. 7; 247-256 (1979).

Bernal, A. de la Rica; et al.: Toxic and side effects of lithium salts in patients under prolonged treatment. (In Spanish.) Actas luso-esp. Neurol. Psi-quiat. 7; 247-256 (1979).

Birch, N.J.; Greenfield, A.A.; Hullin, R.P.: Pharmaco-dynamic aspects of long-term prophylactic lithium. Int. Pharmacopsychiat. 15: 91-98 (1980).

Birch, N.J.; Hullin, R.P.: Lithium and the kidney. Br. med. J. 280: 1148-1149 (1980).

Black, B.L.; Jarett, L.; McDonald, J.M.: Relationship between calcium ion transport and calcium magnesium ATPase in adiposite endoplasmic reticulum. Biochim. biophys. Acta 596: 359-371 (1980).

Blicharski, J.; Aleksandrowicz, J.; Bodzón, A.; Buka-siewịcz, B.; Lisiewịcz, J.: Effect of lithium carbonate on the functional state and the enzymatic equipment of neutrophills in patients with granulo-cytopenia. Revue roum. Méd., Méd. interne 18: 55-60(1980).

Blicharski, J.; Aleksandrowicz, J.; Bodzón, A.; Buka-siewicz, B.; Lisiewicz, J.: Effect of lithium carbonate on the functional state and enzymatic equipment of neutrophils in patients with granulocyto-penia. (In Polish.) Acta hemat. pol. 11. $17-23(1980)$

Blomberg, M.R.A.; Fischer-Hjalmars, I.; Henriksson-Enflo, A.: Model studies on the binding of lithium and beryllium in biological systems. Israel J. Chem. 19: 143-148 (1980).

Bloom, F.E.: Inferential changes after chronic treatments with Li, DMI, or ethanol detected by elec-trophysilological correlates. Psychopharmac, Bull. 16/4: 19-20(1980).

Blum, S.F.: Lithium in hairy-cell leukemia. New Engl. J. Med. 303: 454-465 (1980).

Blum, S.F.: Lithium carbonate therapy of aplastic anemia; in Rossof, Robinson, Lithium effects on gran-ulopoiesis and immune function, p. 333 (Plenum, New York 1980).

Boehm. T.M.; Burman, K.D.; Barnes, S.; Wartofsky, L.: Lithium and iodide combination therapy for thyrotoxicosis. Acta endocr., Copenh. 94: 174-183 (1980).

Boiardi, A.; Bussone, G.: Chronic cluster headache: preliminary data of lithium therapy. Riv. Patol. nerv. ment. 99: 10-13 (1978).

Boland, F.J.; Stern, M.H. Suppression by lithium of voluntary alcohol intake in the rat: mechanism of action. Pharmacol. Biochem. Behav, 12: 239-248 (1980).

Bond, T.C.: Recognition of acute delirious mania. Archs gen. Psychiat. 37: 553-554 (1980).

Bone, S.; Roose, S.P.; Dunner, D.L.; Fieve, R.R.: Incidence of side effects in patients on long-term lithium therapy. Am. J. Psychiat. 137: 103-104 (1980).

Bonnyns, M.; Glinoer, Di,; Ermans, A.: Hypothyroïdie au cours d'un traitement au lithium. (Hypothy-roidism during lithium treatment.) Annl|s Endocr. 41: 222-224 (1980).

Borkowsky, W.; Shenkman, L.; Wadler, S.; Holzman, R.S.; Shopsin, B.: Adjuvant-like effects of lithium on peripheral blood mononuclear cells; in Rossof, Robinson, Lithium effects on granulopoiesis and immune function, pp. 4I7^^27 (Plenum, New York 1980).

Born. G.V.R.; Grignani, G.; Martin, K.: Long-term effect of lithium on the uptake of 5-hydroxytrypt-amine by human platelets. Br. J. clin. Pharmacol. 9: 321-325 (1980).

Boudouresques, G.; Poncet, M.; Ali Cherif, A.; Tafani, B.; Boudouresques, J.: Encéphalopathie aiguë, au cours d'un traitement associant phénothiazine et lithium: une nouvelle observation avec lithémie basse. (Acute encephalopathy during combined phénothiazine and lithium treatment: a new case with low serum lithium concentration.) Nouv. Presse méd. 9: 2580 (1980).

during combined phénothiazine and lithium treatment: a new case with low serum lithium concentration.) Nouv. Presse

Bowden, C.L.; Sarabia, F.: Diagnosing manic-depressive illness in adolescents. Compreh. Psychiat. 21: 263-269(1980). Braccini, T.; Darcourt, G.: Correlations entre la litho-rachịe et les taux de lithium dans le plasma et dans les érythrocytes. (Correlations between the levels of lithium in cerebrospinal fluid and the levels of lithium in blood plasma and
érythrocytes.) Encé-phaleó: 131-137 (1980).

Bressler, P.: An unusual side effect of lithium. Psycho-somatics 21: 688-692 (1980).

Brockington, I.F.; Wainwright, S.; Kendell, R.E.: Manic patients with schizophrenic or paranoid symptoms. Psychol. Med. 10: 73-83 (1980).

Brownhe, B.E.W.; Turner, J.G.; Miller, G.M.B.; Perry,

258

Schou

E.G.; Ding, L.: Lithium-associated thyroid cancer. Aust. N.Z. J. Med. 10:62-63 (1980).

Brownlie, B.E.W.; Turner, T.G.; Ovenden, B.M.; Rogers, T.G. H.: Results of lithium-3, I treatment of thy-rotoxicosis. J. endocr. Invest. 2: 303-305 (1979).

Bucht, G.; Wahlin, A.: Renal concentrating capacity in long-term lithium treatment and after withdrawal of lithium. Acta med. scand. 207: 309-314 (1980). 
Budd, J.L.; Rossof, A.H.: Drinking water lithium levels fail to predict for the incidences of acute or chronic granulocytic leukemia; in Rossof, Robinson, Lithium effects on granulopoiesis and immune function, pp. 411-416 (Plenum, New York 1980).

Burgess, H.A.: When a patient on lithium is pregnant. Am. J. Nursing 79: 1989-1992 (1979).

Bustuoabad, O.D.; Fiocchi, M.G.; Matteucci, I.M.: Alterations in the regeneration of neural structures caused by lithium chloride. Medicina, B. Aires 40: 547-552(1980)

Cameron, O.G.; Landau, S.G.: Lithium carbonate treatment of mania associated with KJinefelter's syndrome. J. Am. med. Ass. 243: 1712 (1980).

Campbell, C.W.B.: Cation induced asymmetry of cho-line flux across presynaptic plasma membranes. Biochim. biophys. Acta 557: 409-424 (1979).

Canessa, M.; Adragna, N.; Solomon, H.S.; Connolly, T.M.; Tosteson, D.C.: Increased sodium-lithium countertransport in red cells of patients with essential hypertension. New Engl. J. Med. 302: 772-776 (1980).

Carlson, G.A.: Lithium carbonate use in adolescents: clinical indications and management; in Feinstein, Giovacchini, Adolescent psychiatry, vol. 7, Developmental and clinical studies, pp. 410-418 (University Chicago Press, Chicago 1979).

Carlson, G.J.: Lithium and hematopoiesis. New Engl. J. Med. 303: 525-526 (1980).

Carney, S.; Thompson, L.; Ralston, M.; Morgan, T.: Lithium administration and urinary electrolyte excretion in the rat. Clin. exp. Pharmacol. Physiol. 7: 437^38 (1980).

Carney, S.L.; Wong, N.L.M.; Dirks, J.H.: Effect of lithium treatment on rat renal tubule function: evidence against impaired antidiuretic hormone action. Nephron 25: 293-298 (1980)

Carvalho, C.A.M.; Carvalho, A.P.: Effect of temperature and ionophores on the permeability of synap-tosomes. J. Neurochem. 33: 309-317 (1979).

Casado de Frias, E.; Balboa de Paz, E.; Perez Martinez, A.; Palacio Mestres, C: Inappropriate secretion of antidiuretic hormone and the effect of lithium in its treatment. J. Pediat. 96 : 153-155 (1980).

Casirola, G.; Invernizzi, R.; Ippoliti, G.; Pavia, G.; Bottoni, A.: Lithium carbonate effects on primitive and secondary neutropenia. Haematologica 65: 746-754 (1980).

Cešková, E.; Náhunek, K.; Švestka, J.: Drug therapy of manic states. Acta Fac. med. Univ. brun. 65: 187-196(1979).

Chan, H.S.L.; Freedman, M.H.; Saunders, E.F.: Stimulation of granulopoiesis in vitro and in vivo using lithium in children with chronic neutropenia; in Rossof, Robinson, Lithium effects on granulopoiesis and immune function, pp. 293-304 (Plenum, New York 1980)

Chan, H.S.L.; Saunders, E.F.; Freedman, M.H.: Modulation of human hematopoiesis by prostaglandins and lithium. J. Lab. clin. Med. 95: 125-132 (1980)

Channabasawanna, S.M.; Sampath, G.; Rao, B.S.S.; Kumar, Y.V.; Krishna, D.K.S.: Lithium response in the treatment of manic symptomatology. Indian J. med. Res. 72 : $908-910$ (1980).

Charron, D.J.; Schmitt, T.; Degos, L.: Clinical investigation of lithium therapy in acute leukemia; in Rossof, Robinson, Lithium effects on granulopoiesis and immune function, pp. 175-186 (Plenum, New York 1980).

Choi, S.J.; Derman, R.M.: Lithium and cholinester-ase. Prog. Neuro-Psychopharmacol. 4: 107-109 (1980).

Chouinard, G.: Mise au point sur Гemploi du carbonate de lithium et les atteintes rénales et thyroïden-nes qui en découlent. (Further considerations on the use of lithium carbonate and the resulting renal and Chouna,

Christensen, S.: Failure of infusion of prostaglandin $\mathrm{A}_{2}$ to restore the response to antidiuretic hormone in rats with polyuria induced by lithium. J. Endocr. 84: 459-465 (1980).

Christensen, S.: DDAVP (/-desamino-8-D-arginine-vasopressin) treatment of lithium-induced polyuria in the rat. Scand. J. clin. Lab. Invest. 40: 151-157(1980).

Christensen, S.; Hansen, B.: Reversibility of lithium-induced impairment of renal concentrating ability in rats. Renal Physiol. 2: 83-89 (1979/80).

Bibliography on the Biology and Pharmacology of Lithium. 9

259

Christiansen, C; Baastrup, P.C.; Transbøl, I.: Development of 'primary' hyperparathyroidism during lithium therapy: longitudinal study. Neuropsycho-biology 6:280-283(1980).

Christie, W.R.: The medical management of the patient with recurrent affective disorder. J. Maine med. Ass. 70: 387-388, 391-394 (1979)

Claux, M.C.: Données actuelles sur les résultats des traitements par les sels de lithium en psychiatrie, et notre experience personnelle. (Recent data on the results of treatments with lithium salts in psychiatry, and our personal experiences); these Toulouse (1978-1979).

Coffey, C.E.; Ross, D.R.: Treatment of lithium/neuro-leptic neurotoxicity during lithium maintenance. Am. J. Psychiat. 137: $736-737$ (1980).

Cohen, B.M.; Miller, A.L.; Lipinski, J.F.; Pope, H.G.: Lecithin in mania: a preliminary report. Am. J. Psychiat. 137: 242-243 (1980).

Cohen, M.R.; Niska, R.W.: Localized right hemisphere dysfunction and recurrent mania. Am. J. Psychiat. 137: 847-848 (1980).

Cohen, M.R.; Niska, R.W.: Localized right hemisphere dysfunction and recurrent mania. Am. J. Psychiat. 137: 847-848 (1980).
Cohen, M.S.; Zahkireh, B.; Metcalf, J.A.; Root, R.K.: Granulocyte function in patients receiving lithium carbonate; in Rossof, Robinson, Lithium effects on granulopoiesis and immune function, pp. 335-346 (Plenum, New York 1980).

Coleman, D.L.; Horwitz, R.I.: Lithium carbonate during chemotherapy. New Engl. J. Med. 302: 1365 (1980).

Colonna, L.; Petit, M.; Lépine, J.-P.; Muscat, P.; Le-moine, J.-M.; Hatte, F.; Edou, D.: Association carbonate de lithium-clométacine et lithémie. (Association of lithium carbonate and clomethazine and blood lithium levels.) Gaz. méd. Fr. 86:4095-4096 (1979).

Colt, E.W.D.; Kimbrell, D.; Fieve, R.R.: Renal impairment, hypercalcemia, and lithium therapy. Am. J. Psychiat. 138: 106-108 (1981).

Conri, C; Simonoff M; Moreau, F.: Diabète insipide temporaire durant un traitement par le carbonate de lithium. (Transient diabetes insipidus during treatment with lithium carbonate.) Concours méd. 101: 5797$5804(1979)$.

Coppen, A.: Lithium in the treatment of alcoholism; in Sandier, Psychopharmacology of alcohol, pp. 209-214 (Raven, New York 1980).

Coppen, A.; Bishop, M.E.; Bailey, J.E.; Cattell, W.R.; Price, R.G.: Renal function in lithium and non-lithium treated patients with affective disorders. Acta psychiat. scand. 62: 343-355 (1980).

Coppen, A.; Cattell, W.R.: Lithium and the kidney. Br. med. J. 281:61 (1980).

Coppen, A.; Swade, C; Wood, K!.: Lithium restores abnormal platelet 5-HT transport in patients with affective disorders. Br. J. Psychiat. 136: 235-238 (1980).

Coronado, R.; Rosenberg, R.L.; Miller, C: Ionic selectivity, saturation, and block in a $\mathrm{K}^{\mathrm{f}}$-selective channel from sarcoplasmic reticulum. J. gen. Physiol. 76 : 425-446 (1980).

Craig, T.J.: Medication use and death attributed to asphyxia among psychiatric patients. Am. J. Psychiat. 137: 1366-1373(1980).

Craig, T.J.; Behar, R.: Trends in the prescription of psychotropic drugs (1970-1977) in a state hospital. Compreh. Psychiat. 21: 336-345 (1980).

Craig, T.J.; Behar, R.: Trends in the prescription of psychotropic drugs (1970-1977) in a state hospital. Compreh. Psychiat. 21: 336-345 (1980).
Crammer, J.L.; Elithorn, A.C.; Lennox, R.: Lithium concentrations and clinical responses; in Porter, Rivers, Whelan, Drug concentrations in neuropsy-chiatry, pp. 81-98 (Elsevier, Amsterdam 1980).

Crouch, E.: Lithium and platelets. Br. J. Psychiat. 137: 197(1980).

Cruaud, D.; Noel, G.; Millot, J.L.: La place du lithium dans le traitement de Thyperthyroïdie. (The place of lithium in the treatment of hyperthyroidism.) Revue fr. Endocr. clin. 18: 29-38 (1977).

Curzon, M.E.J.; Parmeter, D.L.: Lithium and dental caries in the rat. J. dent. Res. 59: 314 (1980).

Dale, P.G.: Lithium therapy in aggressive mentally subnormal patients. Br. J. Psychiat. 137: 469^^74 (1980).

Damasio, H.; Lyon, L. Lithium carbonate in the treatment of cluster headache. J. Neurol. 224: 1-8 (1980).

Danion, J.-M.: L'élimination urinaire du lithium. (The urinary excretion of lithium); these Strasbourg (1979).

Danion, J.-M.: L'elimination urinaire du lithium. (The urinary excretion of lithium); these Strasbourg (1979). dogs.) J. Pharmacol. 11: 89-90 (1980)

Dantzer, R.; Mormède, P.: Effects of lithium on aggressive behaviour in domestic pigs. J. vet. Phar-mac. Ther. 2: 299-303 (1979).

Datta, S.C.: Effects of short-term lithium chloride administration on certain aspects of ascorbic acid metabolism in rats. Indian J. exp. Biol. 18: 877-879 (1980).

Davis, W.M.; Hatoum, N.S.: Synergism of the toxicity

260

Schou

of physostigmine and neostigmine by lithium and by a reserpine-like agent (Ro-1284). Toxicology 17: 1-7 (1980).

Day, B.; Friedman, S.M.: Red cell sodium and potassium in hemorrhagic shock measured by lithium substitution analysis. J. Trauma 20:52-55 (1980).

Denijs, E.L.: Lithium in de klinische praktijk. (Lithium in clinical practice.) Bull. Coord. Commun. Biochem. Onderz. Nzr. 12: 2-13 (1979).

Depue, R.A.; Monroe, S.M.: The unipolar-bipolar distinction in the depressive disorders: implications for stress-onset interactions; in Depue, The psy-chobiology of depressive disorders, pp. 23-53 (Academic Press, New York 1979). 
Descotes, J.; Lievre, M.; Ollagnier, M.; Faucon, G.; Berthezene, F.; Evreux, J.C.: Association propra-nolol-gluconate de lithium et conduction cardia-que: evaluation expérimentale d'un effet dépres-seur éventuel.(Evaluation of the potential cardio-toxicity of propranolol-lithium gluconate association.) Annls Endocr. 41: 127-131 (1980).

Deutsch, J.A.; Gonzalez, M.F.: Food intake reduction: satiation or aversion? Behav. neural. Biol. 24:317-326(1978)

Dinner, P.E.: Ein Fall von bipolarer Affektpsychose mit 48-Stunden-Rhythmus. (A case of bipolar affective psychosis with 48-hour rhythm); Diss. Zurich (1980),

Donker, A.J.M.; Prins, E.; Meijer, S.; Sluiter, W.J.; van Berkestijn, J.W.B.M.; Dols, L.C.W.: A renal function study in 30 patients on long-term lithium therapy. Clin. Nephrol. 12: 254-262 (1979).

Doongaji, D.R.; Jathar, V.S.; Satoskar, R.S.: Manic depressive psychosis in India and the possible role of lithium as a natural prophylactic: I. Hypothesis. J. postgrad. Med. 26: 34-38 (1980).

Dorus, E.; Pandey, G.N.; Schumacher, R.; Davis, J.M.: Role of lithium transport and monoamine oxidase activity in genetic vulnerability to affective disorders. Behav. Genet. 9: 448-449 (1979).

Dorus, E.; Pandey, G.N.; Shaughnessy, R.; Davis, J.M.: Low platelet monoamine oxidase activity, high red blood cell lithium ratio, and affective disorders: a multivariate assessment of genetic vulnerability to affective disorders. Biol. Psychiat. 14: 989-993 (1979).

Dorus, E.; Pandey, G.N.; Shaughnessy, R.; Davis, J.M.: Lithium transport across the RBC membrane: a study of genetic factors. Archs gen. Psychiat. 37: 80-81 (1980).

Dosch, H.-M.; Matheson, D.; Schuurman, R.K.B.; Gelfand, E.W.: Anti-suppressor cell effects of lithium in vitro and in vivo; in Rossof, Robinson, Lithium effects on granulopoiesis and immune function, pp. 447^1.62 (Plenum, New York 1980).

Dotti, A.; Bernini, P.: Indagine catamnestica sulle ra-gioni del $\Gamma$ interruzzione della terapia continuativa con carbonato di litio. (Retrospective investigation of reasons for cessation of maintenance treatment with lithium carbonate.) Riv. Psichiat. 14: 293-307 (1979).

Dreosti, I.E.: Lithium and mania: hypotheses. Med. J. Aust. ;;. 235-236 (1980).

Dufour, H.; Pringuey, D.; Milech, T.; Sutter, J.-M.: A propos des critères prédictifs de Tactivité des sels de lithium en psychiatric (Criteria for predicting response to lithium in psychiatry.) Annls méd. ${ }^{-}$psychol. 138: 504-505 (1980).

Duhm, J.; Becker, B.F.: Studies on lithium transport across the red cell membrane. V. On the nature of the Na ${ }^{\mp}-$ dependent Li $^{\mp}$ countertransport system of mammalian erythrocytes. J. Membr. Biol. 57:263286(1979).

Duhm, J.; Becker, B.F.; Lauf, K.: Ouabain-insensitive sodium-lithium exchange and the effect of anti-L in low potassium sheep erythrocytes. Life Sci. 26: 1217-1222(1980).

Dumont, M.; Mignot, G.: Lithium et grossesse - oui ou non? (Lithium and pregnancy - yes or no?) Nouv. Presse méd. 9: 3625 (1980).

Dumovic, P.; Burrows, G.D.; Chamberlain, K.; Voh-ra, J.; Fuller, J.; Sloman, J.G.: Effect of therapeutic dosage of lithium on the heart. Br. J. clin. Pharmacol. 9: 599-604 (1980).

Dunner, D.L.; Meltzer, H.L.; Fieve, R.R.: Metabolism of lithium in erythrocytes. McLean Hosp. J. 3: 89-97 (1978).

Dunner, D.L.; Murphy, D.; Stallone, F.; Fieve, R.R.: Episode frequency prior to lithium treatment in bipolar manic-depressive patients. Compreh. Psychiat. 20: 511-515 (1979).

Dunner, D.L.; Murphy, D.; Stallone, F.; Fieve, R.R.: Episode frequency prior to lithium treatment in bipolar manic-depressive patients. Compreh.

Dwyer, B.; Wasterlain, C.G.: Regulation of the first step of the initiation of brain protein synthesis by guanosine diphosphate. J. Neurochem. 34: 1639-1647(1980).

Dysken, M.W.; Comaty, J.E.; Pandey, G.N.; Davis, J.M.: Asterixis associated with a high RBC lithium concentration. Am. J. Psychiat. $136:$ 1610 (1979).

Bibliography on the Biology and Pharmacology of Lithium. 9

261

Dysken, M.W.; Halaris, A.E.: Post-ECT asterixis associated with primary hyperparathyroidism. Am. J. Psychiat. 135: 1237-1238 (1978).

Eastwood, R.; Stiasny, S.; Tice, S.: Estimate of the prevalence of bipolar affective disorder: methods based on treatment with lithium. Acta psychiat. scand. 63: 83-90 (1981).

Ebara, T.; Smith, D.F.: Lithium levels in blood platelets, serum, red blood cells and brain regions in rats given acute or chronic lithium salt treatment. J. psychiat. Res. 15: 183-188 (1979).

Ebara, T.; Watanabe, S.; Higashi, S.: A case of acute lithium intoxication with abnormal EEG and prolonged dyssynergia. (In Japanese.) Psychiatria Neurol. jap. 79: 104(1977).

Ebstein, R.P.; Eliashar, S.; Belmaker, R.H.; Ben-Uriah, Y.; Yehuda, S.: Chronic lithium treatment and dopamine-mediated behavior. Biol. Psychiat. /5:459^ $₫ 67(1980)$.

Ebstein, R.P.; Hermoni, M.; Belmaker, R.H.: The effect of lithium on noradrenaline-induced cyclic AMP accumulation in rat brain: inhibition after chronic treatment and absence of supersensibility. J. Pharmac. exp. Ther. 213: 161-167 (1980).

Edelfors, S.: The effect of lithium on the incorporation of ${ }^{32} \mathrm{P}$-orthophosphate into synaptosomal phos-pholipids from rat brain. Acta pharmac. tox. $46: 133-137$ (1980).

Edelfors, S.: The effect of lithium on the incorporation of ${ }^{32} \mathrm{P}$-orthophosphate into synaptosomal phos-pholipids from rat brain. Acta pharmac,
Edelfors, S.: The effect of chronic lithium treatment on the sialic acid content in rat brain synaptosomes. Acta pharmac. tox. 48: 61-64 (1981).

Edelfors, S.: The effect of lithium on the incorporation of ${ }^{3} \mathrm{H}$-glucosamine into glycopeptides and the transformation of ${ }^{3} \mathrm{H}$-glucosamine into sialic acid in rat brain. Acta pharmac. tox. 47: 259-262 (1980).

Editorial: Lithium in haematology. Lancet ii: 626-627 (1980).

Ehrlich, B.E.; Diamond J.M.: Lithium, membranes, and manic-depressive illness. J. Membr. Biol. 52: 187-200(1980).

Ehrlich, B.; Diamond J.M.; Braun, L.D.; Cornford, E.M.; Oldendorf, W.H.: Effects of lithium on blood brain barrier transport of the neurotransmitter precursors choline, tyrosine and tryptophan. Brain Res. 193 . 604-607 (1980).

Ellenberg, J.; Salamon, I.; Meaney, C: A lithium clinic in a community mental health center. Hosp. Com-mun. Psychiat. 31: 834-836 (1980).

Emrich, H.M.; v. Zerssen, D.; Kissling, W.; Möller,

H.-J.; Windorfer, A.: Effect of sodium valproate on mania: the GABA-hypothesis of affective disorders. Arch. Psychiat. NervKrankh. 229: 1-16 (1980).

Engel, J.; Berggren, U.: Effects of lithium on behavior and central monoamines. Acta psychiat. scand. 61: suppl. 280, pp. 133-143 (1980).

Ereshefsky, L.; Saklad, S.R.: Comments on lithium article - a reply. Drug Intell. clin. Pharm. 14: 138 (1980).

Eroglu, L.; Binyildiz, P.; Atamer-Simsek, A.: Lithium-induced changes in the brain levels of free amino acids in stress-exposed rats. Psychopharmacology 70: 187-189 (1980).

Estevez, M.E.; Sen, L.; Herrera, M.D.; Balina, L.M.: Alteración funcional de los macrófagos en pa-cientes con lepra y convivientes sanos. II. Defi-ciencia lítica en convivientes consanguíneos de pa-cientes con lepra lepromatosa. (Functional changes in macrophages of patients with leprosy and healthy subjects. II. Lithium deficiency in relatives of patients with lepromatous leprosy.) Medicina, B. Aires 38: 807 (1978). Evans, L.: Serum lithium levels in Queensland. Med. J. Aust. /:: 314 (1979).

Fadda, F.; Serra, G.; Argiolas, A.; Melis, M.R.; Gessa, G.L.: Effect of lithium on 3,4-dihydroxyphenyl-acetic acid concentrations in different brain areas of rats. Pharmacol. Res. Commun. 12: 689-693 (1980).

Fadda, F.; Serra, G.; Argiolas, A.; Melis, M.R.; Gessa, G.L.: Effect of lithium on 3,4-dihydroxyphenyl-acetic acid concentrations in different brain areas of rats. Pharmacol. Res.

Fernandez, L.A.; Fox, R.A.: Perturbation of the human immune system by lithium. Clin. exp. Immunol. 47:527-532(1980).

Fernandez, L.A.; MacSween, J.M.: Lithium and T cell colonies. Scand. J. Haematol. 25: 382-384 (1980).

Feuerstein, G.; Zilberman, Y.; Hemmendinger, R.; Lichtenberg, D.: Attenuation of the lithium-induced diabetes-insipidus-like syndrome by amilo-ride in rats. Neuropsychobiology 7: 67-73 (1981).

Fieve, R.R.: Lithium and manic-depressive disorders; in Cancero, Shapiro, Kesselman, Progress in the functional psychoses, pp. 161-176 (SP Medical and Scientific Books, Jamaica 1979).

Foster, T.S.; Crass, R.E.; Bustrack, J.A.; Smith, R.B.; Munson, J.W.: Evaluation of two lithium carbon-

262

Schou

ate formulations. Am. J. Hosp. Pharmacy 37: 1528-1530(1980)

Frenkel, E.P.; Herbert, V.: Frequency of granulocytic leukemia in populations drinking high vs. low lithium water. Clin. Res. 22: 390 (1974)

Freyhan, F.A.: The history of recent developments in psychiatry. Compreh. Psychiat. 21: $402^{\wedge} 110(1980)$

Friedenberg, W.R.; Marx, J.J.: Effect of lithium carbonate on lymphocyte, granulocyte, and platelet function. Cancer 45: 91-97 (1980).

Friedenberg, W.R.; Marx, J.J.: The bactericidal effect of neutrophil function with lithium therapy; in Rossof, Robinson, Lithium effects on granulopoie-sis and immune function, pp. 389-399 (Plenum, New York 1980).

Friedman, E.; Dallob, A.; Levine, G.: Effect of long-term lithium treatment on reserpine-induced su-persensitivity in dopaminergic and serotonergic transmission. Life Sci. 25: 1263-1266 (1979).

Fusco, F.A.; Cogliandro, A.; Storace, S.; Carbone, M.; Podesta, M.: Lithium carbonate and granulopoie-sis: clinical and biological experiences. Haemato-logica 65: 818-819 (1980).

Gaillot, J.; Steimer, J.-L.J.; Mallet, A.J.; Thebault, J.J.; Bieder, A.: A priori lithium dosage regimen using population characteristics of pharmacoki-netic parameters. J. Pharmacokinet. Biopharm. 7: 579-628 (1979). 
Galbraith, P.R.: Effect of lithium on colony formation and production of colony-stimulating factor; in Rossof, Robinson, Lithium effects on granulopoie-sis and immune function, pp. 99-109 (Plenum, New York 1980).

Gallager, D.W.; Bunney, W.E.: Effects of chronic lithium administration on the development of super-sensitivity in CNS animal systems: a microionto-phoretic study; in Usdin, Kopon, Barchas, Cate-cholamines: basic clinical frontiers, Proc, 4th Int. Catecholamine Symp., pp. 669-671 (Pergamon, New York 1979).

Gallicchio, V.S.; Chen, M.G.: Modulation of murine pluripotential stem cell proliferation in vivo by lithium carbonate. Blood 56: 1150-1154 (1980).

Garfjnkel, P.E.; Stancer, H.C.; Persad, E.: A comparison of haloperidol, lithium carbonate and their combination in the treatment of mania. J. affect. Dis. 2:279-288(1980).

Geldmacher-Mallinckrodt, M.; Jacob, G.; Scalier, K.H.: Lithium distribution in body fluids and or-

gans after treatment with Quilonum Retard (lithium carbonate). Vet. hum. Toxicol. 21: suppl., pp. 187-190(1979).

Gelfand, E.W.; Cheung, R.; Hastings, D.; Dosch, H.-M.: Characterization of lithium effects on two aspects of T-cell function; in Rossof, Robinson, Lithium effects on granulopoiesis and immune function, pp. 429-446 (Plenum, New York 1980)

Gengo, F.; Frazer, A.; Ramsey, T.A.; Mendels, J.: The lithium ratio as a guide to patient compliance. Compreh. Psychiat. 21: 276-280 (1980)

Gengo, F.; Timko, J.; d’Antonio, J.; Ramsey, T.A.; Frazer, A.; Mendels, J.: Prediction of dosage of lithium carbonate: use of a standard predictive method. J. clin. Psychiat. 41: 319-321 (1980).

Gerner, R.H.; Psarras, J.; Kirschenbaum, M.A.: Results of clinical renal function tests in lithium patients. Am. J. Psychiat. 137: 834-837 (1980)

Ghadirian, A.M.; Lehmann, H.E.: Neurological side effects of lithium: organic brain syndrome, seizures, extrapyramidal side effects, and EEG changes. Compreh. Psychiat. 21 : 327-335 (1980).

Ghose, K.: Interaction between lithium and carbama-zepine. Br. med. J. 280: 1122 (1980).

Giacomini, P.; Gianardi, E.; Marciani, M.G.; Pani-chelli, C: Alterazioni elettroencefalografiche in corso di trattamento con litio. (Electroencephalo-graphic changes during lithium treatment.) Riv. Psichiat. 15: Giacomini, P.; Gan

Gisselmann, A.; Ortega, A.; Marin, A.; Juglaret, M.: Survenue d'une hyperthyroïde chez une psychoti-que traitée par le carbonate de lithium. (Occurrence of hyperthyroidism in a psychotic patient treated with Gisselmann, A.; Ortega, A.; Marin, A.; Juglaret, M.:
lithium carbonate.) Nouv. Presse méd. 9: 379 (1980).

Glick, I.D.; Stewart, D.: A new drug treatment for premenstrual exacerbation of schizophrenia. Compreh. Psychiat. 21: 281-287 (1980)

Glumova, V.A.; Petrov, N.M.; Markov, V.N.: Effect of lithium chloride on the thyroid gland in albino rats. Bull. exp. Biol. Med. 87: 640-643 (1979).

Goett, J.M.; Kay, E.J.: Lithium chloride and delta-9-THC lead to conditioned aversions in the pigeon. Psychopharmacology 72: 215-216 (1981).

Goggans, F.C.: Acute hyperkalemia during lithium treatment of manic illness. Am. J. Psychiat. 137: 860-861 (1980).

Goldberger, E.; Clavere, J.L.; Espagno, J.: Dosage du lithium intra-tumoral (glioblastome cerebral). A propos d'un échec du traitement d'une psychose

Goldberger, E.; Clavere, J.L.; Espagno, J.: Dosage du lithium int
Bibliography on the Biology and Pharmacology of Lithium. 9

263

maniaco-dépressive. (Lithium concentration in a cerebral glioblastoma. A propos of a treatment failure in a case of manic-depressive psychosis.) Encé-phale 6: 139-144(1980).

Gomes, A.; Datta, S.C.: Effects of short-term lithium chloride administration on certain aspects of ascorbic acid metabolism in rats. Indian J. exp. Biol. 18 : 877-879 (1980).

Graham, D.Y.: Lithium carbonate in pancreatic cholera. New Engl. J. Med. 303: 1063 (1980).

Graham, D.Y.; Johnson, G.D.; Bentlif, P.S.; Kelsey, J.R.: Islet cell carcinoma, pancreatic cholera, and vasoactive intestinal peptide. Ann. intern. Med. 83: 782-785 (1975).

Greco, A.M.; de Franciscis, P.; Bozza, P.; Salvatore, M.: Funzionalità tiroidea e metabolismo lipidico in ratti trattati con litio e dieta nath colesterolo-priva. (Thyroid function and lipid metabolism in rats treated with lithium and atherogenic diet without cholesterol.) Boll. Soc, ital. Biol. sper. 55: 2589-2595 (1979).

Greco, F.A.: Lithium attenuation of chemotherapy-induced granulocytopenia: statistical and clinical significance? in Rossof, Robinson, Lithium effects on granulopoiesis and immune function, pp. 275-279 (Plenum, New York 1980).

Greco, F.A.: Lithium and immune function in man; in Rossof, Robinson, Lithium effects on granulopoiesis and immune function, pp. $463-469$ (Plenum, New York 1980).

Greffe, J.: Cinétique du lithium dans le sang et dans Гurine après prise unique chez des sujets volon-taires et chez un malade traité au long cours. (Phar-macokinetics of lithium in blood and urine after a single Greffe, J.: Cinétique du lithium dans le sang et dans Turine après prise unique chez des sujets volon-taires et chez
dose given to volunteers and after long-term treatment given to a patient.) Psychol. méd. 11: 1971-1975 (1980).

Grenberg, P.L.; Packard, B.; Steed, S.M.: Effects of lithium chloride on human and murine marrow myeloid colony formation and colony stimulating activity; in Rossof, Robinson, Lithium effects on granulopoiesis and immune function, pp. 137-144 (Plenum, New York 1980).

Griffith, M.J.; Beavers, G.; Kingdon, H.S.; Lundblad, R.L.; Effect of monovalent cations on the heparin enhanced antithrombin III thrombin reaction. Thromb. Res. 17: 29-39 (1980).

Grivtsev, B.A.; Pirogova, N.I.: Lithium in the central nervous system tissue in radiation sickness. (In Russian.) Med. Radiol., Mosk. 25: 73-75 (1980).

Grof, P.; Lane, J.: Lithium and memory loss. Can. J. Psychiat. 24:784(1979).

Grof, P.; MacCrimmon, D.J.; Smith, E.K.M.; Daigle, L.; Saxena, B.; Varma, R.; Grof, E.; Keitner, G.; Kenny, J.: Long-term lithium treatment and the kidney: interim report on fifty patients. Can. J. Psychiat. 25:

Grof, P.; MacCrimmon, D.J.; Smith, E.K.M.; Daigle, L.; Saxena, B.; Varma, R.; Grof, E.; Keitner, G.; Kenny, J.: Long-term lithium tre
535-544 (1980).

Grof, P.; Smith, E.K.M.: The effects of lithium treatment on the kidney function and structure. Can. psychiat. Ass. Bull. 11: 6-8 (1979).

Grohmann, R.; Strauss, A.; Gehr, C; Rüther, E.; Hip-pius, H.: Zur Praxis der klinischen Therapie mit Psychopharmaka. (On the practice of clinical therapy with psychotropic drugs.) Pharmakopsychiatr. NeuroPsychopharmakol. 13: 1-19(1980).

Gruen, P.H.; Sachar, E.J.; Langer, G.; Altman, N.; Leifer, M.; Frantz, A.; Halpern, F.S.; Prolactin responses to neuroleptics in normal and schizophrenic subjects. Archs gen. Psychiat. 35: 108-116 (1978).

Guelen, P.J.M.: Clinical pharmacokinetics of lithium; in Merkus, Serum concentration of drugs, pp. 106-113 (Excerpta Medica, Amsterdam 1980).

Guerri, C; Grisolia, S.: Potentiation of ethanol toxic-ity by lithium; in Eriksson, Sinclair, Kiianmaa, Animal models in alcohol research, pp. 323-328 (Academic Press, London 1980).

Gupta, K.D.; Jefferson, J. W.: Lithium and 'accidentally' induced food aversion. J. clin. Psychiat. 41: 364 (1980).

Hamburger, S.; Covinsky, J.; Uhrig, L.; Shaffer, K.: Lithium carbonate therapy for granulocytopenia in a patient with myelofibrosis and septic arthritis. Sth. med. J. 72: 1601-1602 (1979).

Hammond, W.P.; Appelbaum, F.: Lithium and acute monocytic leukemia. New Engl. J. Med. 302: 808 (1980).

Hammond, W.P.; Dale, D.C.: Lithium therapy of canine cyclic hematopoiesis. Blood 55: 26-28 (1980)

Hammond, W.P.; Dale, D.C.: Lithium treatment of cyclic hematopoiesis in the gray collie; in Rossof, Robinson, Lithium effects on granulopoiesis and immune function, pp. 167-173 (Plenum, New York 1980). Han, B.H.; Influences of lithium and ethanol on convulsions and hyperglycemia induced with picro-toxin. (In Korean.) Taehan Yakrihak Chapchi 75: 21-27 (1979).

Hansen, H.E.; Amdisen, A.: Den kliniske betydning af

264

Schou

litiums akutte og kroniske nefrotoksicitet. (The clinical significance of the acute and chronic neph-rotoxícity of lithium.) Ugeskr. Læg. 142: 2206-2208 (1980).

Hanuš, H.; Zapletálek, M.; Kindernayova, H.; Kuce-rova, H.: Clinical experience with lithium carboni-cum retard in psychiatry. Activitas nerv. sup. $22: 175$ (1980).

Hanuš, H.; Zapletálek, M.; Stránský, P.: EEG in patients treated with lithium. Activitas nerv. sup. 21: 164-166(1979).

Hariharasubramanian, N.; Parvathi Devi, S.; Venkoba Rao, A.: Lithium ion and pineal RNA: a preliminary report. Indian J. Psychiat. 18: 215-218 (1976).

Harrison-Read, P.E.: Behavioral evidence for increased dopaminergic activity after long-term lithium pretreatment in rats. IRCS Med. Sci., Libr. Compend. S: 313 (1980).

Hartter, D.E.; Ramirez, V.D.: The effects of ions, metabolic inhibitors, and colchicine on luteinizing hormone-releasing hormone release from super-fused rat hypothalami. Endocrinology 107: 375-382 (1980).

Hassanyeh, F.; Davison, K..: Bipolar affective psychosis with onset before age 16 years: report of 10 cases. Br. J. Psychiat. 137: 530-539 (1980).

Hasue, I.; Kurihara, M.; Uchigata, M.; Tanabe, H.; Nihei, H.; Mimura, N.; Yoshimoto, Y.: A case of lithium intoxication with neurological sequelae. (In Japanese.) Clin. Evaluat. 5: 435^3/845 (1977).

Hatotani, N.; Nomura, J.; Yamaguchi, T.; Inoue, K.; Kitayama, I.: Studies on the treatment of periodic psychoses. Folia psychiat. neurol. jap. 34: 184 (1980).

Haynes, W.F.; Elmore, J.L.: Lithium toxicity. J. med. Soc. New Jers. 76: 655-659 (1979).

Hedde, J.P.; Quinke, J.; Müller, J.: Thyreoidaler Re-gelkreis unter langfristiger Lithium-Medikation. (Thyroidal regulation during long-term lithium treatment.) Nuklearmedizin, Stuttg., suppl. 16: pp. 728-731 (1978). 
Heimpel, H. Stimulation of hematopoiesis in aplastic anemia by hormones and other agents. Haemat. Bluttransf. 24: 129-137 (1979).

Hendy, M.S.; Dove, A.F.; Arblaster, P.G.: Mazindol-induced lithium toxicity. Br. med. J. 280: 684-685 (1980)

Héraud, G.: Incidents et accidents des traitements par le lithium. (Side effects and complications of lith-

ium therapy.) Gaz. méd. Fr. 87: 2111-2122 (1980).

Herbert, V.; Colman, N.: Release of vitamin binding proteins from granulocytes by lithium: vitamin B12 and folate binding proteins; in Rossof, Robinson, Lithium effects on granulopoiesis and immune function, pp. 61-78 (Plenum, New York 1980).

Hermoni, M.; Lerer, B.; Ebstein, R.P.; Belmaker, R.H.: Chronic lithium prevents reserpine-induced supersensitivity of adenylate cyclase. J. Pharm. Pharmac. 52: 510-511 (1980).

Herrmann, W.M.; Kropf, D.; Fichte, K.; Müller-Oer-linghausen, B.: Elektroenzephalografische und psy-choexperimentelle Untersuchungen mit Lithium an gesunden Probanden. (Electroencephalographic and psychoexperimental studies in healthy subjects on lithium medication.) Pharmakopsychiatr. Neuro-Psychopharmakol. 75: 200-212 (1980).

Heurteaux, C; Wissocq, J.C.; Stelz, T.; Thellier, M.: Microlocalisation quantitative du lithium dans le cerveau de la Souris. (Quantitative microlocaliza-tion of lithium in the mouse brain.) Biol. Cellulaire 55: 251258 (1979).

Himmelhoch, J.M.; Neil, J.F.: Neuroleptics, mood-state, and lithium-provoked tardive extrapyrami-dal symptoms; in Usdin, Eckert, Forrest, Pheno-thiazines and structurally related drugs: basic and clinical studies, pp. 341-344 (Elsevier, New York 1980).

Himmelhoch, J.M.; Neil, J.F.; May, S.J.: Chronic mania, tardive dyskinesia and post-synaptic cate-cholaminergic hypersensitivity; in Usdin, Eckert, Forrest, Phenothiazines and structurally related drugs: basic and clinical studies, pp. 345-348 (Elsevier, New York 1980)

Himmelhoch, J.M.; Neil, J.F.; May, S.J.; Fuchs, C.Z.; Licata, S.M.: Age, dementia, dyskinesias, and lithium response. Am. J. Psychiat. 137: 941-945 (1980).

Hirschowitz, J.; Casper, R.; Garver, D.L.; Chang, S.: Lithium response in good prognosis schizophrenia. Am. J. Psychiat. 137: 916-920 (1980).

Hoppe, A.; Metier, M.; Angielski, S.: Wpyw litu na stan równowagi kwasowo-zasadowej krwi szczu-rów. (Effect of lithium on the acid-base equilibrium in rat blood.) Diagn. Lab. 75: 111-117 (1979). Horodnicki, J.M.; Wasik, A.; Firko, M.; Janicka, B.: Effect of lithium ions on the activity of glycolysis

Bibliography on the Biology and Pharmacology of Lithium. 9

265

enzymes in the brain and the peripheral blood leukocytes in rats. (In Polish.) Psychiat. pol. 13: 543-548 (1979).

Horrobin, D.F.; Manku, M.S.: The possible role of prostaglandin El in the affective disorders and in alcoholism. Br. med. J. 280: 1363-1366 (1980).

Hwang, S.; Tuason, V.B.: Long-term maintenance lithium therapy and possible irreversible renal damage. J. clin. Psychiat. 41: 11-19 (1980)

Imandt, L.; Tyhuis, D.; Wessels, H.; Haanen, C: Observations on ADP aggregation of lithium chloride-incubated platelets in a variety of mammalian species. Haemostasis 9: 276-287 (1980)

Iovchuk, N.M.: Late results of lithium treatment of adolescents with attack-like schizophrenia. (In Russian.) Zh. Nevropat. Psikhiat. 80: 1546-1548 (1980).

Ishigura, S.; Miyao, N.: Effects of lithium chloride on the activity of rat liver tryptophan oxygenase. (In Japanese.) Kagoshina Daigaku Nogakubu Gaku-jutsu Hokoku 30: 193-199 (1980).

Issidorides, M.R.: Lykouras, E.P.; Papadimitriou, G.N.; Panayotacopoulou, M.T.; Christodoulou, G.N.: Histochemical changes of peripheral blood leukocytes during lithium treatment; in Christodoulou, Aspects of preventive psychiatry. Biblthca psychiat., No. 160, pp. 38^14 (Karger, Basel 1981).

Izquierdo, J.A. de la Torre: Litio y agresividad. (Lithium and aggressiveness); in Jimeno, I curso mono-grafico sobre agresividad, pp. 53-65 (Delagrange, Salamanca 1980).

Jackson, B.A.; Dousa, T.P.: Adenylate cyclase and cAMP-phosphodiesterase in medullary tubules of rats with lithium-induced polyuria. Clin. Res. 28: 449 (1980).

Jackson, B.A.; Edwards, R.M.; Dousa, T.P.: Lithium-induced polyuria: effect of lithium on adenylate cyclase and adenosine-3',5'-monophosphate phos-phodiesterase in medullary ascending limb of Henle's loop and in medullary collecting tubules. Endocrinology 707: 1693-1698 (1980).

Jamison, K.R.; Gerner, R.H., Hammen, C; Padesky, C: Clouds and silver linings: positive experiences associated with primary affective disorders. Am. J. Psychiat. 137: 198-202 (1980).

Janka, Z.; Szentistvanyi, I.; Juhasz, A.; Rimanoczy, A.: Difference in lithium transport between neurones and glia in primary culture. Neuropharma-cology 79:827-830(1980).

Janka, Z.; Szentistvanyi, I.; Juhasz, A.; Rimanoczy, A.: Steady-state distribution of lithium during cultivation of dissociated brain cells. Experientia 36: 1071-1073 (1980).

Janka, Z.; Szentistvanyi, I.; Rimanoczy, A.; Juhasz, A.: The influence of external sodium and potassium on lithium uptake by primary brain cell cultures at 'therapeutic' lithium concentration. Psychopharmacology 71: 159-163 (1980).

Jankovic, B.D.; Isakovic, K.; Popeskovic, L.: Negative immune deviation induced by lithium cation. Immunol. Lett. 1: 203-208 (1980).

Jefferson, J.W.: The use of lithium in children. Int. Drug Ther. Newslett. 75: 25-28 (1980).

Jefferson, J.W.: Diuretics are dangerous with lithium. Br. med. J. 281: 1217(1980).

Jefferson, J.W.; Greist, J.H.: Haloperidol and lithium: their combined use and the issue of their compatibility; in Ayd, haloperidol update: 1958-1980, pp. 73-82 (Ayd Medical Communications, Baltimore 1980). Jefferson, J.W.; Greist, J.H.: Some hazards of lithium use. Am. J. Psychiat. 138: 93-94 (1981).

Jim, R.T.S.: Chronic myeloid leukemia and lithium. Ann. intern. Med. 92: 262 (1980).

Johnson, F.N.: Immunological aspects of lithium therapy. IRCS Med. Sci., Libr. Compend. 7: 375-376 (1979)

Johnson, F.N.: Social and psychological support ad-junctive to lithium therapy: a critical review. Int. J. Psychiat. Med. 10: 255-264 (1980/81).

Johnson, F.N.: Effects of lithium chloride on lateral line response in Carassius auratus. Naturwissen-schaften 67: 515-516 (1980)

Johnson, F.N.: The effects of lithium chloride on spontaneous alternation behaviour in the goldfish (Carassius auratus). Neuropsychobiology 6: 72-78 (1980).

Johnson, F.N.: Effects of alkali metal chlorides on activity levels of rats in a passive exploration test. Int. J. Neurosci. 10: 85-88 (1980).

Johnson, F.N.: Lithium responsiveness - the psychological connection. IRCS Med. Sci., Libr. Compend. 8: 343-346 (1980).

Johnson, G.; Hunt, G.; Jackson, D.; Richards, T.; Kwan, E.: Pharmacokinetics of standard and a sustained-release lithium carbonate preparation: Priadel. Med. J. Aust. ii: 382 (1979).

Johnson, G.; Kuchel, P.W.; Singh, B.S.; Hunt, G.E.; Begg, W.B.; Jones, A.J.: Red-cell choline in manic-

266

Schou

depressive patients taking lithium. New Engl. J. Med. JØJ: 705 (1980).

Johnson, J.H.; Crookshanks, H.R.; Smalley, H.E.: Lithium toxicity in cattle. Vet. hum. Toxicol. 22: 248-251 (1980)

Johnsson, A.; Engelmann, W.; Pflug, B.; Klemke, W.: Influence of lithium ions on human circadian rhythms. Z Naturf. 35.503-507 (1980).

Johnston, B.B.; Naylor, G.J.; Dick, E.G.; Hopwood, S.E.; Dick, D.A.T.: Prediction of clinical course of bipolar manic depressive illness treated with lithium. Psychol. Med. 10: 329-334 (1980).

Jonderko, G.; Marcisz, C: Kurzzeitige Lithiumkar-bonatanwendung zur Behandlung der Thyreotoxi-kose. (Short-term use of lithium carbonate in the treatment of thyrotoxicosis.) Z. ges. inn. Med. 34: 408-411 (1979).

Jonderko, G.; Marcisz, C; Smrek, M.; Kawecka, E.: Short-term administration of lithium carbonate as a method of therapeutic management of thyrotoxicosis. (In Polish.) Polski Tygod lek. 34: 1237-1240 (1979). Jones, A.J.; Kuchel, P.W.: Measurement of choline concentration and transport in human erythrocytes by "H NMR: comparison of normal blood and that from lithium-treated psychiatric patients. Clinica chim. Acta 104: 77-85 (1980).

Jope, R.S.; Jenden, D.J.; Ehrlich, B.E.; Diamond, J.D.; Gosenfeld, L.F.: Erythrocyte choline concentrations are elevated in manic patients. Proc., natn. Acad. Sci. USA 77: 6144-6146 (1980).

Joyce, R.A.; Chervenic, P. A.: The effect of lithium on release of granulocyte colony stimulating activity in vitro; in Rossof, Robinson, Lithium effects on granulopoiesis and immune function, pp. 79-86 (Plenum, New York 1980).

Joyce, R.A.; Chervenick, P.A.: Lithium effects on granulopoiesis in mice following cytotoxic chemotherapy; in Rossof, Robinson, Lithium effects on granulopoiesis and immune function, pp. 145-154 (Plenum, New York 1980)

Kajda, P.K.; Birch, N.J.: Lithium inhibition of rabbit muscle phosphofructokinase. Ciencl, Bilol., Coim-bra5: 103-104(1980).

Kajda, P.K.; Birch, N.J.; O’Brien, M.J.; Hullin, R.P.: Rat-brain pyruvate kinase: purification and effects of lithium. J. inorg. Biol. 11: $361-366$ (1979).

Kalinowsky, L.B.: The discoveries of somatic treatments in psychiatry: facts and myths. Compreh. Psychiat. 21: 428^3/835 (1980). 
Kalvach, Z; Chumchal, O : A case of trigeminal neuralgia treated with lithium carbonate. Activitas nerv, sup. 21: 168-169(1979).

Kamlana, S.H.; Kerry, R.J.; Khan, I.A.: Lithium: some drug interactions. Practitioner 224: 1291- 1292 (1980).

Kammen, D.P. van; Alexander, P.E.; Bunney, W.E.: Lithium treatment in post-psychotic depression. Br. J. Psychiat. 136: 479-485 (1980).

Kammerer, F.; Villeneuve, A.: Lithium et fonction rénale. (Lithium and renal function.) Encéphale 6: 227-240 (1980)

Kampf, D.; Albrecht, J.; Müller-Oerlinghausen, B.: Klinisch-nephrologische Befunde bei Patienten mit Lithium-Langzeittherapie. (Clinical-nephro-logical findings in patients on long-term lithium treatment.) Arzneimittel-Forsch. 30: 1225-1226 (1980)

Kardos, G. D.; Farkas, J.; Sónyi, G.: Über die protekti||ve Lithium-Medikation bei periodischen Alkoholi-kern. (Protective lithium treatment of periodic alcoholics.) Protialk. Obz., Bratisl. 13:144-147 (1978). Kariya, T.: Manic-depressive psychosis and amine metabolism. Folia psychiat. neurol. jap. 34: 162 (1980).

Kariya, T.; Kobayashi, K.; Yu, M.; et a),: Clinical and neurochemical studies on the therapeutic effect and side effects of lithium carbonate in manic-depressive reaction. (In Japanese.) Seishin-Yaku-ryo-KikinKenkyu-Nempo 2: 30-35 (1970).

Kaskey, G.B.; Salzman, L.F.; Ciccone, J.R.; Klorman, R.: Effects of lithium on evoked potentials and performance during sustained attention. Psychiat. Res. 5:281-289(1980).

Katz, R.J.: Lithium and the structure of exploratory behavior in the rat. Prog. Neuro-Psychopharma-col. ¥: $37^{\wedge * 2}(1980)$.

Kawano, K.: Fundamental and clinical studies in lithium carbonate therapy of manic-depressive psychosis. (In Japanese.) Kyushu Neuro-Psychiat. 24: 22-40 (1978).

Keller, B.; Graefe, K.-H.: The inhibitory effect of some monovalent cations on the stimulation by sodium ion of the neuronal uptake of noradrenaline. Arch. Pharmakol. 309: 89-98 (1979).

Kempen, G.M.J. van; Fabius, A.J.M.: Lithiumbloed-spiegels bij gebruik van verschillende preparaten. (Lithium blood levels on use of various preparations.) Bull. Coord. Commun. Biochem. Onderz. Nzr. 77: $74-$ 76 (1978).

Bibliography on the Biology and Pharmacology of Lithium. 9

267

Kennedy, P.: The use of psychiatric drugs for decades. Br. J. Psychiat. 137: 387-389 (1980).

Kerry, R.J.; Ludlow, J.M.; Owen, G.: Diuretics are dangerous with lithium. Br. med. J. 281: 371 (1980).

Kersten, L.: The pharmacokinetics of lithium in rats of different ages. Acta biol. med. germ. 38: 1331-1345 (1979).

Khanna, N.K.; Vyas, D.S.; Pendse, V.K.; Sanghavi, A.: Lithium in the modern treatment of psychosis. Curr. med. Pract. 24: 1-5 (1980).

Kijne, B.; Rasmussen, H.; Kirk, L.: Lithiumdosis og allder. (Lithium dosage and age.) Ugeskr. Læg. 143: 119-120(1981).

Kjellman, B.F.; Karlberg, B.E.; Thorell, L.-H.: Cognitive and affective functions in patients with affective disorders treated with lithium. Acta psychiat. scand. 62:32-46(1980).

Kolomaznik, M.; Musil, F.; Suva, J.: Lithium level in some biological fluids at its prophylactic-therapeutic application. Activitas nerv. sup. 21: 169 (1979).

König, L.: The lithium dose in relation to body weight and age in the prophylaxis of relapses in manic-depressive psychosis. Agressologie 21: 15-17 (1980)

Krakiewicz, A.; Kiejna, A.: Powiklania ze strony os-rodkowego ukladu nerwowego w czasie terapii li-tem. (Complications in the central nervous system during lithium therapy.) Psychiat. pol. 14: 63-67 (1980).

Kripke, D.F.; Wyborney, V.G.: Lithium slows rat cir-cadian activity rhythms. Life Sci. 26: 1319-1323 (1980).

Kripke, D.F.; Wyborney, V.G.; McEachron, D.: Lithium slows rat activity rhythms. Chronobiologia 6: 122 (1979).

Kripke, D.F.; Wyborney, V.G.; McEachron, D.: Lithium slows rat activity rhythms. Chronobiologia 6: 122 (1979).

Kropf, D.: Probleme und Konzepte der Lithium-For-schung aus psychologischer Sicht. (Problems and concepts of lithium research from a psychological point of view.) Pharmakopsychiatr. Neuro-Psychopharmacol. 13: 168-174(1980).

Kukopulos, A.; Reginaldi, D.; Laddomada, P.; Floris, G.; Serra, G.; Tondo, L.: Course of the manic-depressive cycle and changes caused by treatment. Pharmakopsychiatr. Neuro-Psychopharmacol. 13: 156-167 (1980).

Kurtzman, N.A.: 'Short-circuit' renal tubular acidosis. J. Lab. clin. Med. 95: 633-636 (1980).

Ladimer, I.: Combined lithium-haloperidol therapy: legal aspects; in Ayd, Haloperidol update: 1958 - 1980, pp. 93-101 (Ayd Medical Communications, Baltimore 1980).

Lahmeyer, H.W.: Gaviria, M.: Bradycardia, persistent diabetes insipidus, and tardive dyskinesia with lithium intoxication. Psychiat. J. Univ. Ottawa 5: 283-286(1980).

Lam, E.; Tu, S.I.: Effects of monovalent cations on the activities associated with coupling site III of rat liver mitochondria. Biochem. biophys. Res. Com-mun. 96: 196-202(1980).

Lambert, P.A.: Histoire des psychotropes. (History of psychotropic drugs.) Evolut. psychiat. 45: 669-689 (1980).

Lapierre, G.; Stewart, R.B.: Lithium carbonate and leukocytosis. Am. J. Hosp. Pharmacy 37: 1525-1528(1980).

Lapierre, Y.D.; Gagnon, A.; Kokkinidis, L.: Rapid recurrence of mania following lithium withdrawal. Biol. Psychiat. 75: 859-864 (1980).

Latimer, N.Z.; Chin, E.; Garson, O.M.: Sister chroma-tid exchanges in the lymphocytes of humans on long-term lithium therapy. Mutat. Res. 74: 421-422(1980).

Lawas, I.E.; Delacruz, J.R.R.: Plasma-red cell lithium activity as a guide to manic-depressive lithium therapy. Phillipine intern. Med. 17: 204-211 (1979).

Ledoux, J.-M.: La pharmacocinétique comparée du lithium. (The comparative pharmacokinetics of lithium); these Toulouse (1980).

Ledoux, J.-M.: La pharmacocinétique comparee du lithium. (The comparative pharmacokinetics of lithium); these Toulouse (1980).

Lena, B.: Lithium therapy in hyperaggressive behavior in adolescents; in Sandier, Psychopharmacology of aggression, pp. 197-204 (Raven Press, New York 1979).

Leucuta, S.; Pop, R.; Kory, M.; Toader, S; Bohm, B.; Melian, E.: Pharmacokinetics and bioavailability of lithium administered to dogs as monoglutamate and carbonate. Pharm. Acta Helv. 54: $343-346$ (1979).

Levitt, L.J.; Quesenberry, P.J.: The effect of lithium on murine hematopoiesis in a liquid culture system. New Engl. J. Med. 302: 713-719 (1980).

Levitt, L.J.; Quesenberry, P.J.: Lithium and hematopoiesis. New Engl. J. Med. 303: 526 (1980).

268

Schou

Lieb, J.: Linoleic acid in the treatment of lithium tox-icity and familial tremor. Prostagland. Med. 4: 275-280 (1980).

Lieb, J.: Prostaglandin E, in affective disorders and alcoholism. Br. med. J. 281: 453 (1980)

Lieb, J.; Lombard, D.; Nazzaro, A.: Lithium treatment of hypothermia caused by electric shock. Med. Hypotheses 6: 769-772 (1980).

Lieberman, K.W.; Stokes, P.: Lithium distribution ratios in psychiatrically normal subjects. Pharmacol. Biochem. Behav. 13: 205-208 (1980).

Lieberman, K.W.; Stokes, P.: Entry of lithium into erythrocytes. Res. Commun. Psychol. Psychiat. Behav. 5:231-234(1980).

Lim, B.S.; Harris, R.; Solomon, J.D.: Electron microscopic observations of renal lesions caused by lithium carbonate: hypertrophy of endothelial and epithelial cells. Micron 10: $241-245$ (1979).

Lin, C.I.; Vasalle, M.: The effect of lithium on stro-phanthidin toxicity in cardiac Purkinje fibers. Proc. Soc. exp. Biol. Med. 164: 212-216 (1980).

Lindegård, B.: Alcoholism, lithium and selection bias; in Lindegård, Common mental disorders, pp. 1-6 (Socialmedicinsk Information, Gothenburg 1980)

Lins, R.; de Broe, M.E.: Ernstige vergiftiging tijdens onderhoudsbehandeling met litiumcarbonat. (Severe intoxication during maintenance treatment with lithium carbonate.) Ned. Tijdschr. Geneesk. 724:545-548 (1980).

Lippmann, S.: Lithium in depressed chronic alcoholics. Rhode İsl. med. J. 63: 22-24 (1980).

Lobo, A.; Escolar, V.; Stokes, P.E.: Estudio de 100 enfermos maníaco depresivos: II. Evaluacion pros-pectiva del tratamiento con litio: deterioro social, efectos secundarios del medicamento y aspectos psicosomaticos. (A study of 100 manic-depressive patients: II. Follow-up study of the lithium carbonate treatment, secondary effects and psychosomatic aspects.) Commun. psiquiat. 5: 197-224 (1980).

Lobo, A.; Pauker, N.; Stokes, P.E.: Una clínica de litio para el tratamiento continuado de enfermos man-íaco-depresivos. (A lithium clinic for the continued treatment of manic-depressive patients.) Actas luso-esp.

Lobo, A.; Pauker, N.; Stokes, P.E.: Una clínica de litio para el tratamiento continuado de enfermos man-íaco-depresivos. (A lithium clinic for
Neurol. Psiquiat. 4: 303-316 (1976).

Logan, J.G.: In vitro effects of lithium chloride on ATPases of rabbit cerebral synaptic membranes. Biochem. Pharmac. 29: 887-890 (1980).

Lolasstepke, F.; Harding, G.F.; Jenner, F.A.; Damas-

mora, J.: Studies on changing laterality index in a patient treated with lithium; in Gruzelier, Florhen-ry, Hemisphere asymmetries of function in psy-chopathology. Developments in psychiatry, vol. 3, pp. 255-257

(Elsevier, Amsterdam 1979).

Longo, D.L.: More on lithium and leukemia. New Engl. J. Med. 505:283(1980). 
Lôo, H.; Amic, J.: Lithium and mood disorders. Per-spect. psychiat. 15: 13-18 (1977).

Lôo, H.; Cuche, H.: Perspectives biochimiques du traitement de la depression. (Biochemical perspectives in treatment of depressive illness.) Annls Biol. clin. 57:65-72 (1979).

Lowance, D.: Heat injury: a possible association with lithium carbonate therapy. J. Med. Ass. Ga 69: 284-286(1980).

Lyman, G.H.; Williams, C.C; Dinwoodie, W.R.; Preston, D.: The effect of lithium carbonate administration in patients with advanced small cell bronchogenic carcinoma receiving combination chemotherapy and radiotherapy; in Rossof, Robinson, Lithium effects on granulopoiesis and immune function, pp. 207-229 (Plenum, New York 1980).

Lyman, G.H.; Williams, C.C; Preston, D.: The use of lithium carbonate to reduce infection and leukope-nia during systematic chemotherapy. New Engl. J. Med. 502:257-260(1980).

Lyman, G.H.; Williams, C.C; Preston, D.: Lithium carbonate during chemotherapy. New Engl. J. Med. 302: 1365(1980).

Lyubimov, B.I.; Samoilov, N.N.; Goryanov, O.A.: Effect of diuretics on lithium chloride toxicity. (In Russian.) Farmak. Toks. 43: 625-628 (1980).

Lyubimov, B.I.; Tolmacheva, N.S.; Ostrovskaya, R.U.; Mitrofanov, V.S.: Experimental study of neurotropic activity of lithium oxybutyrate. (In Russian.) Farmak. Toks. 43: 273-276 (1980),

Maccabe, E.R.B.; Melvin, T.R.; Obrien, D.; Montgomery, R.R.; Robinson, W.A.; Bhasker, C; Brown, B.I.: Neutropenia in a patient with type-IB glycogen storage disease: in vitro response to lithium chloride. J. Pediat. 97: 944-945 (1980).

MacCallum, W.A.G.: Interaction of lithium and phe-nytoin. Br. med. J. 280: 610-611 (1980)

MacDonald, K.J.; Little, P.J.; Bailey, R.R.: Lithium and the kidney. N.Z. med. J. 90: 323-325 (1979).

McGee, J.L.; Alexander, B.; Perry, P.J.: Lithium citrate syrup and trifluoperazine hydrochloride concentrate incompatibility: effect on serum lithium

Bibliography on the Biology and Pharmacology of Lithium. 9

269

levels. Am. J. Hosp. Pharmacy 37: 1052-1058 (1980).

McGlone, J.J.; Kelley, K.W.; Gaskins, C.T.: Lithium and porcine aggression. J. Anim. Sci. $51: 447^{133} / 85$ (1980)

McGlone, J.J. Ritter, S.; Kelley, K.W.: The antiaggres-sive effect of lithium is abolished by area postrema lesion. Physiol. Behav. 24: 1095-1100 (1980).

MacGregor, R.R.; Dyson, W.L.: Inhibition of granulo-cyte adherence by lithium: possible relationship to lithium-induced leukocytosis; in Rossof, Robinson, Lithium effects on granulopoiesis and immune function, pp. 347-355 (Plenum, New York 1980).

Mackay, A.V.P.; Sheppard, G.P.; Saha, B.K.; Motley, B.; Johnson, A.L.; Marsden, CD.: Failure of lithium treatment in established tardive dyskinesia. Psychol. Med. 10: $583-587$ (1980).

Madhyastha, N.A.; Gopaldutt, N.H. Short-term lithium-induced histological changes in thyroid and pituitary glands of the spiny mouse Mus-Platythrix (Bennett). Indian J. exp. Biol. 18 : $471-475$ (1980).

Maggi, A.; Enna, S.J.: Regional alterations in rat brain neurotransmitter systems following chronic lithium treatment. J. Neurochem. 34: 888-892 (1980).

Májský, A.; Dvofáková, M.; Zvolský, P.: Binding of lithium and neuroleptịcs in lymphocyte HLA antigens in vitro. Folia haemat. Lpz. 707: 74-80 (1980)

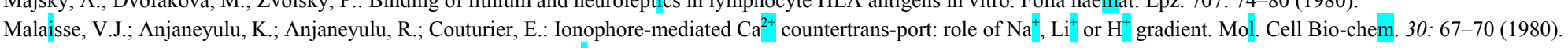

Mallinger, A.G.; Mallinger, J.; Himmelhoch, J.M.; Neil, J.F.; Haninn, I.: Transmembrane distribution of lithium and sodium in erythrocytes of depressed patients. Psychopharmacology 68: 249-255 (1980).

Malt, U.: Lithium i klinisk psykiatri. (Lithium in clinical psychiatry.) (Universitetets psykiatriske Insti-tut, Oslo 1980).

Mandel, M.R.; Madsen, J.; Miller, A.L.; Baldessarini, R.J.: Intoxication associated with lithium and ECT. Am. J. Psychiat. 137: 1107-1109 (1980).

Mandell, A.J.: On the mechanism for the mood and personality changes of adult and later life: a psy-chobiological hypothesis. J. nerv. ment. Dis. 167: 457-466(1979).

Mandell, A.J.; Knapp, S.; Geyer, M.A.: Lithium decreases and cocaine increases the bilateral asymmetry of serotonin in neostriatal and neurolimbic systems associated with changes in the kinetic properties of tryptophan hydroxylase; in Usdin, Kopin, Barchas, Catecholamines: basic clinical frontiers, Proc, 4th Int. Catecholamine Symp., pp. 663-665 (Pergamon, New York 1979).

Manzoni, G.C.; Terzano, M.G.: Lithium carbonate in chronic cluster headache: assessment of therapeutic efficacy and possible mechanisms of action. Ital. J. neurol. Sci. 1: 149-154 (1980).

Manzoni, G.C.; Terzano, M.G.; Parma, M.: Condotta terapeutica nel trattamento della cefalea a grappolo con carbonato dil litio. (Lithium in the treatment of cluster headache.) Minerva med., Roma 71: 947-952(1980)

Marcy, T.W.; Forrest, J.N.: Amiloride reverses chronic lithium-induced polyuria by a mechanism dependent on antidiuretic hormone. Clin. Res. 28: 455 (1980).

Margakis, V.P.: Depot injections for affective disorders. Br. J. Psychiat. 136: 408 (1980).

Margo, A.: Failure of lithium therapy. Am. J. Psychiat. 137: 752 (1980).

Mate, C; Ribas, B.; Acobettro, R.I.; Santos Ruiz, A.: Lithium and rubidium effects on the motor activity of rats. An. R. Acad. Farm. 45:279-286 (1979).

Mattsson, A.; Seltzer, R.L.: Lithium carbonate and gastric ulcer. Am. J. Psychiat. 138: 124 (1981).

Mayo, J.A.; O'Connell, R.A.; O’Brien, J.D.: Families of manic-depressive patients: effect of treatment. Am. J. Psychiat. 136: 1535-1539 (1979).

Medina, J.L.; Fareed, J.; Diamond, S.: Lithium carbonate therapy for cluster headache: changes in number of platelets and serotonin and histamine levels. Archs Neurol. 37: 559-563 (1980).

Medras, M.; Knapik-Kordecka, M.; Tucci, M.: Pier-wotna, utrwalona niedoczynnos̆c tarczyjy jako po-wịklanie przewleklej terapii weglanem litu. (Primary stabilized hypothyroịdism as a complication of long-term treatment with lithium carbonate.) Wiad. lek. 33: 217-219 (1980).

Megrabian, A.A.; et al.: Lithium carbonate treatment of schizoaffective psychoses. (In Russian.) Zh. eksp. klin. Med. 19: 54-58 (1979).

Megrabian, A.A.; Khachatryan, A.M.; Amadyan, M.G.; Burnazyan, G.A.: Lithium carbonate treatment of manic-depressive psychosis. (In Russian.) Zh. eksp. klin. Med. 19: 79-84 (1979).

Megra
270

Schou

Meinhold, J.M.; Spunt, A.L.; Trịrath, C: Bíoavailabil-ity of lithium carbonate: in vivo comparison of two products. J. clin. Pharm. 19: 701-703 (1979).

Melese, F.: Effets rénaux du lithium: diabète insipide néphrogénique. (Renal effects of lithium: nephro-genic diabetes insipidus); these Paris (1980).

Mellerup, E.T.; Dam, H.; Widding, A.; Rafaelsen, O.J.: Chronobiological aspects of manic-melancholic disorders; in Saletu et al., Neuro-psycho-pharmacology, pp. 247-254 (Pergamon, New York 1979).

Mellerup, E.T.; Rafaelsen, O.J.: Circadian rhythms in manic-melancholic disorders; in Essman, Valzelli, Current developments in psychopharmacology, pp. 51-56 (Spectrum, New York 1979).

Mendlewicz, J.; Verbanck, P.M.P.: Cell membrane anomaly as a genetic marker for manic-depressive illness. Am. J. Psychiat. 138: 119 (1981).

Messiha, F.S.; El-Domeiri, A.; Sproat, H.F.: Effects of lithium and cesium salts on sarcoma-II implants in the mouse. Neurobehav. Toxicol. 1: 27-31 (1979).

Mickel, R.A.: The effect of lithium ions on carbohydrate metabolism in rat skeletal muscle and brain. Diss. Abstr. Int. B 40: 3179-3180 (1980).

Mifune, M.: Determination of lithium in serum by emission spectrophotometry using ‘spectraspan’. (In Japanese.) Okayama Daigaku Onsen Kenkyu-sho Hokoku 50: 43-48 (1980).

Mignot, G.: Lithium et grossesse. (Lithium and pregnancy); these Lyon (1977).

Mikhailova, N.M.; Seventy, A.A.: Withdrawal effect of a prolonged prophylactic lithium treatment. (In Russian.) Zh. Nevropat. Psikhiat. 80: 1216-1220 (1980)

Millington, W.R.; Mccall, A.M.; Wurtman, R.J.: Lithium administration potentiates the effect of exogenous choline on brain acetylcholine levels; in Bar-beau, Growdon, Wurtman, Nutrition and the brain, vol. 5, Choline and lecithin in brain disorders, pp. 417-424 (Raven Press, New York 1979).

Min, S.K.; Lee, K.S.: Effects of sulfur and lithium on blood alcohol level in rabbits. Korean Neuropsy-chiat. Ass. 70:9-15 (1971).

Mitchell, D.; Wells, C; Hoch, N.; Lind, K.; Woods, S.C.; Mitchell, L.K.: Poison-induced pica in rats. Physiol. Behav. 17: 691-697 (1976).

Miyamoto, M.; Tamura, H.; Takeuchi, H.; Endo, I.: Different effects of the replacement of sodium in

the extracellular medium with lithium on the abnormal spike discharge caused by two convulsants, metrazole and strychnine, in an identifiable giant neuron of the mollusk Achatina fulica ferussac, (In French.) C.r. Séanc, Soc, Biol. 174: 285-289 (1980).

Miyauchi, T.; Oikawa, S.; Kitada, Y.: Effects of lithium chloride on the cholinergic system in different brain regions in mice. Biochem. Pharmac. 29:654-657 (1980).

Molcan, J.; Motýlová, A.; Rakús, A.: Pharmakokine-tische Studie des Lithium-retard bei affektiven Psychosen. (Pharmacokinetic study of lithium retard in affective psychoses.) Agressologie 21: suppl. A, pp. 1114(1980).

Molnar, G.; Dajka, K; Baraczka, K: A lithium ion hatása a szérum fehérjék fluoreszcenciájára. (The effect of the lithium ion on the fluorescence of serum protein.) Ideggyóg. Szle 33: 184-187 (1980)

Moskowitz, J.A.: Lithium and Lady Luck: use of lithium carbonate in compulsive gambling. N.Y. St. J. Med. 80: 785-788 (1980).

Muehlen, H. von der: Der «geordnete Dämmerzu-stand» als lithiuminduzierte Komplikation. ('OOrdered twilight state’ as complication of lithium therapy.) Psycho 4: 174-176 (1978).

Mühlbauer, H.; Hardt, W.: Der Einfluss von Lithium und Antidepressiva auf den Serum-Prolaktin-Spie-gel. (The influence of lithium and antidepressants on the serum prolactin level.) Pharmakopsychiatr. Neuro-

Psychopharmakol. 13: 213-217 (1980). 
Müller-Oerlinghausen, B.; Passoth, P.-M.; Poser, W ; Pudel, V : Impaired glucose tolerance in long-term lithium-treated patients. Int. Pharmacopsychiat. 74:350-362(1979).

Myers, J.B.; Morgan, T.O.; Carney, S.L.; Ray, C: Effects of lithium on the kidney. Kidney 18: 601-608 (1980).

Nagel, W.: Influence of lithium upon the intracellular potential of frog skin epithelium. J. Membr. Biol. 37: 347-359 (1977).

Náhunek, K; Sláma, B.; Kulísková, O.; Kamenická, V.: Study of effects of single doses of psychotropic drugs in healthy volunteers. Acta Fac, med. Univ. brun. 65: 197-210(1979).

Nair, V.; Hariprasad, M.K.; Weiss, A.: Lithium carbonate, hypothyroidism, and serum creatinine phosphokinase level. J. Am. med. Ass. 243: 1231- 1232 (1980)

Bibliography on the Biology and Pharmacology of Lithium. 9

271

Nally, J.V.; Rutecki, G.W.; Ferris, T.F.: The acute effect of lithium on renal renin and prostaglandin E synthesis in the dog. Circulation Res. 46: 739-744 (1980).

Nam, J.-H.: A study of toxic symptoms due to lithium overdosage. Neuropsychiatry 28: $266-275$ (1979).

Narayanan, H.S.; Rao, B.S.S.R.; Channabasavanna, S.M.: Monitoring of serum lithium levels in manic-depressive psychosis. Indian J. med. Res. 72 : $712-715$ (1980).

Nelson, S.C; Herman, M.M.; Bensch, K.G.; Barchas, J.D.: Localization and quantitation of lithium in rat tissue following intraperitoneal injections of lithium chloride. 2. Brain. J. Pharmac, exp. Ther. 212: 11-15 (1980).

Newgreen, D.B.; Grigor, J.M.: Lithium in a state mental health service. Med. J. Aust. ii: 99 (1980).

Nielsen, J. Lanng: Development of acute myeloid leukemia during lithium treatment. Acta haemat. 63: 172-174(1980).

Nielsen, J. Lanng: Development of acute myeloid leukemia during lithium treatment. Acta her

Nolen, W.A.; Jensen, G.S.: Calcium, magnesium and therapeutic effect of lithium. (In Dutch.) Bull. Coord. Commun. Biochem. Onderz. Sect. Geeste-lijke Gezondheidszorge Natn. Ziekenhuilsraad 13: 23-24 (1980).

Nordenberg, J.; Kaplansky, M.; Beitner, R.: Influence of lithium on glucose 1,6-diphosphate levels in muscle of normal and dystrophic mice. İRCS Med. Sci., Libr. Compend. 8: 880-881 (1980).

Nyfeler, F.; Walter, P.: Effect of lithium on glycogen synthesis in hepatocytes from rat liver. FEBS Lett. 108: 197-200(1979).

Ogawa, N.; Yamakawi, Y.; Ofuji, T.: Properties of opioid receptor binding in rat brain. Folia endocr. jap. 56:27-36(1980).

Okpaku, S.; Frazer, A. Mendels, J.: A pilot study of racial differences in erythrocyte lithium transport. Am. J. Psychiat. 137: 120-121 (1980)

Olesen, O.V.; Hestbech, J.; Thomsen, K. Potassium reduction of lithium-induced histological changes of the rat kidney. Toxicol. appl. Pharmacol. 55. 79-84(1980).

Olesen, O.V.; Hestbech, J.; Th, Pen, K.: Potassium reducto

Olesen, O.V.; Thomsen, K.: Renal response to potassium infusion in rats given lithium for prolonged time. Acta pharmac. tox. 46: 185-190 (1980)

Opgenoorth, E.; Lenz, G.; Sperlich, S.; Wytek, R.: Multivariate Zusammenhänge im Leistungsver-halten von Lithium-Patienten. (Reactivity of patients under lithium therapy: assessment of multivariate relationships.) Pharmakopsychiatr. Neuro-Psychopharmakol. 13: 182-199 (1980).

Oredipe, O.A.; Stohs, S.J.: Effects of lithium on time to onset of aconitine-induced initial arrhythmia and ventricular tachycardia. Archs int. Pharmaco-dyn. Thér. 240: 249-256 (1979).

Osanloo, E.; Deglin, J.H.: Interaction of lithium and methyldopa. Ann. intern. Med. 92: 433-434 (1980).

Ostrow, D.G.; Southam, A.S.; Davis, J.M.: Lithium-drug interactions altering the intracellular lithium level: an in vitro study. Biol. Psychiat. 15:723-739 (1980).

Othmer, E.; Powell, B.; Piziak, V.K.; Preskorn, S.H.: Prospective use of saliva lithium determinations to monitor lithium therapy. J. clin. Psychiat. 40: 525-526(1979).

Oulés, J.; Boscredon, J.: Le lithium peut-il être, aussị, antidépresseur? (Is lithium also an antidepressant?) C.r. Congr. Psychiat. Neurol. Langue fr. 75: 1111-1117 (1977).

Pakes, G.E.: Eye irritation and lithium carbonate. Archs Ophthal., N.Y. $98: 930$ (1980).

Pandey, G.N.; Davis, J.M.: Biology of the lithium ion; in Rossof, Robinson, Lithium effects on granulo-poiesis and immune function, pp. 15-59 (Plenum, New York 1980).

Pandol, S.J.; Korman, L.Y.; Gardner, J.D.: Lithium carbonate in pancreatic cholera. New Engl. J. Med. 303: 1064 (1980)

Pandol, S.J.; Korman, L.Y.; McCarthy, D.M.; Gardner, J.D.: Beneficial effect of oral lithium carbonate in the treatment of pancreatic cholera syndrome. New Engl. J. Med. 302: 1403-1404 (1980).

Park, J.M.; Sridaromont, S.; Ledbetter, E.O.; Terry, W.M.: Ebstein anomaly of the tricuspid valve associated with prenatal exposure to lithium carbonate. Am. J. Dis. Child. 134: 703-704 (1980).

Parvathi Devi, S.; Hariharasubramanian, N.; Venkoba Rao, A.: Pineal gland responses to lithium and chlorpromazine. Indian J. Psychiat. 18: 208-214 (1976).

Parvathi Devi, S.; Venkoba Rao, A.; Hariharasubramanian, N.: Pineal gland responses to lithium and chlorpromazine; in Nir, Reiter, Wurtman, The pi272

Schou

neal gland, pp. 387-388 (Springer, New York 1978).

Paschalis, C; Pavlou, A.; Papadimitriou, A.: A stepped forty-eight hour manic-depressive cycle. Br. J. Psychiat. 137: 332-336 (1980).

Paykel, E.S.; Rowan, P. R. Affective disorders; in Granville-Grossman, Recent advances in clinical psychiatry, No. 3, pp. 37-90 (Churchill Livingstone, London 1979).

Peet, M.; Coppen, A.: Lithium treatment and prophylaxis in unipolar depression. Psychosomatics 21: 303-313(1980).

Perez, H.D.; Kaplan, H.B.; Goldstein, I.M.; Shenk-man, L.; Borkowsky, W.: Reversal of an abnormality of leukocyte chemotaxis with lithium. Clin. Immunol. Immunopathol. 16: 308-315 (1980).

Perez, H.D.; Kaplan, H.B.; Goldstein, I.M.; Shenk-man, L.; Borkowsky, W.: Effects of lithium on polymorphonuclear leukocyte chemotaxis; in Ros-sof, Robinson, Lithium effects on granulopoiesis and immune function, pp. 357-370 (Plenum, New York 1980).

Perez, L.; Marcus-Ofseyer, B.: The effect of lithium treatment on the behavior and paintings of a psychotic patient with religious and sexual conflicts. Am. J. Art Ther. 17: 85-90 (1978).

Periac, P.; Paraf, A.; Fischer, D.: Aplasie médullaire au cours d'une hepatite. Evolution favorable. Role de traitement par le lithium. (Transient bone marrow aplasia associated with hepatitis: possible effect of lithium therapy.) Sem. Hop. Paris 56: 176-180(1980).

Pert, C.B.; Pert, A.; Rosenblatt, J.E.; Tallman, J.F.; Bunney, W.E.: Catecholamine receptor stabilization: a possible mode of lithium's anti-manic action; in Usdin, Kopin, Barchas, Catecholamines: basic clinical Pert, C.B.; Pert, A.; Rosenblatt, J.E.; Tallman, J.F.; Bunney, W.E.: Catecholamine receptor s

frontiers, Proc. 4th Int. Catecholamine Symp., pp. 583-585 (Pergamon, New York 1979).
Perucca, E.; Richens, A.: Interaction between lithium and carbamazepine. Br. med. J. 280: 863 (1980).

Pesando, P.; Nuzzi, G.; Maraini, G.: Bilateral papill-oedema in long-term therapy with lithium carbonate. Pharmakopsychiatr. Neuro-Psychopharma-kol. 13: 235-239 (1980).

Peselow, E.D.; Dunner, D.L.; Fieve, R.R.; Deutsch, S.I.; Kaufman, M.: Lithium prophylaxis of depression in bipolar II patients. IRCS Med. Sci.., Libr. Compend. 8: $367-368$ (1980).

Peselow, E.D.; Dunner, D.L.; Fieve, R.R.; Deutsch,

S.I.; Lautin, A.: The use of the life-table in evaluating lithium prophylaxis in bipolar-II patients and other affective subtypes. IRCS Med. Sci., Libr. Compend. 8: 680-682 (1980).

Peselow, E.D.; Dunner, D.L.; Fieve, R.R.; Lautin, A.: Lithium carbonate and weight gain. J. affect. Dis. 2:303-310(1980).

Peselow, E.D.; Gubelkian, G.; Dunner, D.L.; Fieve, R.R.; Burdock, E.I.: Lithium, tricyclics and lithium + tricyclics in the prophylaxis of unipolar illness. IRCS Med. Sci., Libr. Compend. 8: 524-527 (1980).

Pestronk, A.; Drachman, D.B.: Lithium reduces the number of acetylcholine receptors in skeletal muscle. Science 210: 342-343 (1980).

Petersen, K.P.: Effect of age and route of administration on $\mathrm{LD}_{50}$ of lithium chloride in the rat. Acta pharmac. tox. 47: 351-354 (1980)

Petterson, U.: Erfarenheter från en litiumdispensär. (Experiences from a lithium clinic.) Läkartid-ningen 77: 1845-1847 (1980).

Pílug, B.; Hartung, M.; Klemke, W.: Die Beeinflus-sung von Befindlichkeit und Leistungsfähigkeit gesunder Versuchspersonen durch Lithiumcar-bonat. (The effect of lithium carbonate on mood and performance of healthy subjects.) Pharmakopsychiatr. Neuro-Psychopharmakol. 13: 175-181 (1980).

Pflug, B.; Martin, W.: Analyse circadianer Tempera-turgänge bei endogener Depression. (Analysis of circadian temperature rhythm in endogenous depression.) Arch. Psychiat. NervKrankh. 229: 127143(1980).

Phillips, R.H.: Psychoactive drugs and the creative urge. Lancet $i i$ : 1143 (1980).

Pi, E.H.; Dempsey, G.M.: Lithium carbonate in aplas-tic anemia. Archs gen. Psychiat. 37: 720 (1980).

Pierre, D.; Leprince, A.: Intoxication par les sels de lithium. (Intoxication with lithium salts.) Revue méd. Tours 13: $731-738$ (1979).

Platz, W.: Vereinfachte Lithium-Einstellung: klinische Erfahrungen mit einem Belastungstest. (Simplified lithium adjustment: clinical experience with a tolerance test.) Munch, med. Wschr. 722: 353-354 (1980). Pohl, R.W.; Revusky, S.; Mellor, C.S.: Drugs employed in the treatment of alcoholism: rat data suggest they are unnecessarily severe. Behav. Res. Therapy /S: 71-78 (1980).

Poirel, C; Hengartner, O.; Briand, M.: Circadian 
rhythms and periodicity analyses of emotional behaviors in mice treated with lithium. Adv. Biiosci. 19: 171-178 (1979).

Pope, H.G.; Lipinski, J.F.; Cohen, B.M.; Axelrod, D.T.: 'Schizoaffective disorder': an invalid diagnosis? A comparison of schizoaffective disorder, schizophrenia, and affective disorder. Am. J. Psy-chiat. 137: 921-927 (1980).

Popeskovic, L.; Jankovic, B.D.; Isokovic, K.: Effect of lithium on immunological reactivity in CBA mice. Periodicum biologorum 81: 179-181 (1979).

Post, R.M.: Sensitization and oscillation following repeated stimulation: relationship to affective illness and its treatment with lithium and carbama-zepine. Psychopharmac. Bull. 16/4: 50-52 (1980).

Prakash, R.; Sethi, N.: Lithium in saliva and serum: some observations. Indian J. Psychiat. 21: 256-258(1979).

Prasad, V.; Sheard, M.H.: The acute and chronic effect of lithium on serum testosterone in rats. Commun. Psychopharmacol. 4: 147-152 (1980).

Pratịla, M.G.; Pratịlas, V.: ST depression under anesthesia in a patient on lithium carbonate. Mount Sinai J. Med. 46: 549-551 (1979).

Prien, R.: Update on lithium - 1979-1980. Psychopharmac. Bull. 16/4: 13-15 (1980).

Propping, P.; Friedl, W.: Genetic influences on phar-macodynamic properties of psychotropic drugs. Pharmacology 19: 1-4 (1979).

Ptashne, K.; Stockdale, F.E.; Conlon, S.: Initiation of DNA synthesis in mammary epithelium and mammary tumors by lithium ions. J. cell. Physiol. 103: 41-46 (1980).

Puzanová, L.; Doskocil, M.: Teratogenic effect of lithium salts on young chick embryos. Folia morph. 27:26-30(1979).

Radecki, T.: Patient preference: lithium pills versus capsules. Am. J. Psychiat. 137: 259-260 (1980).

Rao, A. Venkoba: Lithiumology. Indian J. Psychiat. 20:3 (1977).

Rao, A.V.; Hariharasubramanian, N.: Electrocardio-graphic changes during lithium treatment. Indian J. Psychiat. 22: 135-141 (1980).

Rapp, M.S.; Thomas, M.R.: Lithium and memory loss. Can. J. Psychiat. 24: 700-701 (1979)

Raszeja-Specht, A.: Wpiyw przewleklego podawania chlorku litu na funkcje nerek. (Effect of long-term administration of lithium on renal function.) Dịagn. Lab. 14: 111-120(1978).

Reading, H.W.: Calcium release and aggregation in

rabbit platelets: action of psychotropic drugs. Cell, mol. Biol. 25: 421-427 (1979).

Reading H.W. Isbir, T. Action of lithium on ATPase in the rat iris and visual cortex. Biochem. Phar-mac. 25:3471-3474(1979).

Reading, H.W.; Rosie, R.: Effects of lithium and halo-peridol on blood platelet function. Biochem. Soc. Trans. 7:933-935(1979).

Rector, W.G.; Jarzobski, J.A.; Levin, H.S.: Sinus node dysfunction associated with lithium therapy: report of a case and a review of the literature. Nebr. med. J. 64: 193 (1979)

Reifman, A.; Wyatt, R.J.: Lithium: a brake in the rising cost of mental illness. Archs gen. Psychiat. 37: 385-388 (1980).

Rektor, L.; Horká, E.: Neurotoxicita lithia. I. (Lithium neurotoxicity. I.) Cslká Psychiat. 75: 232-235 (1979)

Rektor, L.; Horká, E.: Neurotoxicita lithia. II. (Lithium neurotoxicity. II.) Cslká Psychiat. 76: 8-15 (1980).

Reynolds, D.R.; Foxworth, J.M.: Prophylactic treatment of alcoholism with lithium salts: a review. J. S. Carol, med. Ass. 76: 58-60 (1980).

Richman, A.V.; Masco, H.L.; Rifkin, S.I.; Acharya, M.K.: Minimal-change disease and the nephrotic syndrome associated with lithium therapy. Ann. intern. Med. 92: $70-71$ (1980).

Ritchie, J.M.; Straub, R.W.: Observations on the mechanism for the active extrusion of lithium in mammalian non-myelinated nerve fibres. J. Physiol., Lond. 304: 123-134(1980).

Ritter, S.; McGlone, J.J.; Kelley, K.W.: Absence of lithium-induced taste-aversion after area postrema lesion. Brain Res. 201: 501-506 (1980).

Robak, O.H.: Litiumbehandlingens status i 1979/1980. (The status of lithium treatment in 1979/1980.) Tidsskr. norske Lægeforen. 100: 1376-1378 (1980)

Robinson, W.A.; Entringer, M.A.; Huber, J.; Gupta, R.: In vivo and in vitro effects of lithium on gran-ulopoiesis in human neutropenic disorders; in Rossof, Robinson, Lithium effects on granulopoie-sis and immune function, pp. 281-291 (Plenum, New York 1980).

Rodland, K.D.; Dunham, P.B.: Kinetics of lithium efflux through the (Na, K)-pump of human erythro-cytes. Biochim. biophys. Acta 602: 376-388 (1980).

Roger, P.; Mauriac, L.; Kern, A.-M.; Schmitt, B.;

274

Schou

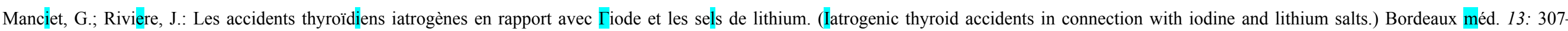
309(1980)

Roman, I.; Gmaj, P.; Nowicka, C; Angielski, S.: Regulation of calcium efflux from kidney and liver. Eur. J. Biochem. 102: 615-623 (1979).

Rose, I.A.; Warms, J.V.B.: Lithium action on glucose uptake in brain: role of glucose-1,6-diphosphate as a regulator of hexokinase. Biochem. biophys. Res. Commun. 92: 1030-1036 (1980).

Rosen, B.P.; Futa, M.: Sodium/proton antiporter of rat liver mitochondria. FEBS Lett. 117: 39-43 (1980).

Rosenbaum, A.H.: Manic-depressive illness and pregnancy. J. Am. med. Ass. 243: 1089 (1980).

Rosenbaum, A.H.; Maruta, T.; Duane, D.D.; Auger, R.G.; Martin, D.K.; Brenengen, E.E.: Tardive dys-kinesia in depressed patients: successful therapy with antidepressants and lithium. Psychosomatics 27:715$721(1980)$.

Rosenblatt, J.E.; Pert, A.; Layton, B.; Bunney, W.E.: Chronic lithium reduces $\left[{ }^{3} \mathrm{H}\right]$ spiroperidol binding in rat striatum. Eur. J. Pharmacol. 67: 321-322 (1980).

Rosenstock, J.; Archer, J.; Pequignot, E.: Effect of lithium on acute myelocytic leukemia cells in tissue culture-a preliminary study; in Rossof, Robinson, Lithium effects on granulopoiesis and immune function, pp. 401-409 (Plenum, New York 1980).

Rosenthal, N.E.; Rosenthal, L.N.; Stallone, F.; Fleiss, J.; Dunner, D.L.; Fieve, R.R.: Psychosis as a predictor of response to lithium maintenance treatment in bipolar affective disorder. J. affect. Dis. 7: 237-245 Rosent

$(1979)$

Rosman, A.W.; Sczupak, C.A.; Pakes, G.E.: Correlation between saliva and serum lithium levels in manic-depressive patients. Am. J. Hosp. Pharmacy 37: 514-518 (1980)

Rossof, A.H.; Budd, J.L.: Drinking water levels fail to predict for the incidences of acute or chronic gran-ulocytic leukemia. Clin. Res. 28: 322 (1980)

Rossof, A.H.; Fehir, K.M.; Budd, H.S.; Murthy, A.; Economou, S.G.: Lithium carbonate enhances granulopoiesis and attenuates cyclophosphamide-induced injury in the dog; in Rossof, Robinson, Lithium effects on granulopoiesis and immune function, pp. 155-166 (Plenum, New York 1980).

Rossof, A.H.; Robinson, W.A.: Lithium effects on

granulopoiesis and immune function (Plenum, New York 1980).

Roth, B.; Smolik, R.; Soucek, K.: Kleine-Levinuv syn-drom - lithioprofylaxie. (Kleine-Levin syndrome -lithium prophylaxis.) Cslká Psychíat. 76: 156-162 (1980).

Rothstein, G.; Oshita, A.K.; Harker, W.G.; Lonngi, G.; Christensen, R.D.: The effect of lithium upon granulocyte production in vitro and in vivo in the mouse; in Rossof, Robinson, Lithium effects on granulopoiesis and immune function, pp. 87-98 (Plenum, New York 1980).

Ruszaz, C; Schab, R.; Mess, B.: Central effect of lithium on the activity of the thyrotropic hormone-thyroid system. Neuroendocrin. Lett. 2: 191-198 (1980).

Rybakowski, J.: Badanie transportu litu przez blone komorkowa w chrobie afektywnej dwubiegunowej na modelu krwinki czerwonej. (Study of lithium transport through cell membrane in bipolar affective disorder on the model of red cell.) Polski Tygod lek. 35: 103-105 (1980).

Rybakowski, J.; Chlopocka-Wozniak, M.; Kapelski, Z.; Strzyzewski, W.: The relative prophylactic efficacy of lithium against manic and depressive recurrences in bipolar patients. Int. Pharmacopsy-chiat. 15: 8690 (1980).

Rybakowski, J.; Kapelski, Z.; Strzyzewski, W.: Przy-datnošc wskažnika krwinkowego litu dla oceny za-burzeń transportu jonowego u chorych z zespolami depresyjnymi. (Usefulness of the erythrocyte lithium index for the evaluation of disorders of ion transport in depressive syndromes.) Psychiat. pol. 75:217-222 (1979).

Sachdev, H.S.; Brodsky, L.: Lithium carbonate: therapeutic agent for spasmodic torticollis. Psychosomatics 20: 831-836 (1979)

Saghafi, D.; Mehandru, S.K.; Penico, P.E.: Lithium toxicity associated with peripheral edema: a case report. Kidney int. 16: 937 (1979).

Salem, R.B.; Director, K.; Muniz, C.E.: Ataxia as the primary symptom of lithium toxicity. Drug Intell. 74:622-623(1980).

Samoilov, N.N.; Lyubimov, B.I.; Sholokov, V.M.; Pe-trov, V.M.: Effects of psychotropic agents on lithium pharmacokinetics. (In Russian.) Byull. eksp. Biol. Med. 89: 696-698 (1980).

Sampath, G.; Kumar, Y.V.; Narayanan, H.S.; Rama Rao, B.S.S.: Lithium neurotoxicity at 'therapeutic' levels: a case report. Indian J. Psychiat. 22: 304-306(1980). 
Sampath, G.; Rama Rao, B.S.S.; Channabasavanna, S.M.; Subash, M.: Intra and extra erythrocyte lithium ion concentration ratios in manic patients. Indian J. Psychiat. 22: 176-178 (1980) Saneto, R.P.; Srivastava, S.K.; Werrbach-Perez, K.; Perez-Polo, J.R.: Lithium uptake at physiological ion concentrations in a human clonal neuroblas-toma cell line. J. Neurochem. 34: 1520-1521 (1980). Sangdee, C; Franz, D.N.: Lithium enhancement of central 5-HT transmission induced by 5-HT precursors. Biol. Psychiat. 15: 59-75 (1980).

Saratikov, A.S.; Alekseeva, L.P.; Agarkova, V.P.; Za-moshchina, T.A.: Effect of lithium hydroxybuty-rate on the excitability of the cortex and some sub-cortical structures in the rabbit brain. (In Russian.) Byull. eksp. Biol. Med. 88: 574-576 (1979).

Saratikov, A.S.; Alekseeva, L.P.; Agarkova, V.P.; Za-moshchina, T.A.: Effect of lithium hydroxybuty-rate on cortical and subcortical excitability in rabbits. Bull. exp. Biol. Med. 88: 1312-1315 (1979).

Saratikov, A.S.; Alekseeva, L.P.; Agarkova, V.P.; Za-moshchina, T.A.: Effect of lithium hydroxybuty-rate on bioelectrical activity of the cortex and some subcortical structures of the rabbit brain. (In Russian.) Farmak. Toks. 43: 353-356 (1980)

Saviskii, I.V.; Grivtsev, B.A.; Gotsulyak, L.E.: Changes in lithium content of hemopoietic organs and tissues of irradiated rabbits. (In Russian.) Ra-diobiologiya 20: 436-438 (1980)

Savoldi, F.; Nappi, G.; Bono, G.: Lithium salts in treatment of idiopathic headaches and of facial pain syndromes. Riv. Patol. nerv. ment. 99: 4-9 (1978).

Savoldi, F.; Tartara, A.; Bo, P.; Zerbi, F.: Trattamento cronico con sali di litio ed attività elettrica cere-brale: richerche sperimentali. (Long-term treatment with lithium salts and brain electrical activity: experimental research.) Boll. Soc, ital. Biol. sper. 55:668-674(1979)

Schlesinger, H.R.; Frazer, A.; Friedman, R.; Mendels, J.; Hummeler, K.: Lithium ion uptake associated with the stimulation of action potential ionophores of cultured human neuroblastoma cells. Life Sci. 25:957-967(1979).

Schlienger, J.L.; Drui, S.; Alt, R.; Reville, P.; Stephan, F.: Intérêt du carbonate de lithium dans deux cas d’hyperthyroïde grave. (Place of lithium carbonate in two cases of severe hyperthyroidism.) J. Méd. Strasbourg 11: 17-18(1980)

Schnerman, J.; Ploth, D.W.; Hermle, M.: Activation of tubuloglomerular feedback by chloride transport. Pfliigers Arch. ges. Physiol. 362: 229-240 (1976).

Schottlander, P.; Litka, P.A.; Arkel, Y.S.: Chronic granulocytic leukemia with normal leukocyte alkaline phosphatase score in a patient receiving lithium carbonate. J. med. Soc. New Jers. 77:197-198 (1980).

Schou, M.: Lithiumbehandhng af manio-depressiv sygdom: En vejledning. (Lithium treatment of manic-depressive illness: an instruction.) (Arkona, Aarhus 1978).

Schou, M.: Lithium treatment of manic-depressive illness: a practical guide (Karger, Basel 1980).

Schou, M.: Lithium-Behandlung der manisch-depres-siven Krankheit: Information furr Arzt und Pa-tienten. (Lithium treatment of manic-depressive illness: information for doctor and patients.) (Thieme, Stuttgart 1980).

Schou, M.: Litiumbehandling av manio-depressiv sjukdom: en vägledningng. (Lithium treatment of manic-depressive illness: a practical guide.) (Astra Läkemedel, Södertälje 1981).

Schou, M.: Pharmacology and toxicology of lithium; in Hoffmeister, Stille, Psychotropic agents. I. An-tipsychotics and antidepressants, pp. 583-590 (Springer, Berlin 1980)

Schou, M.: Linoleic acid in the treatment of lithium-induced tremor: a pilot trial with negative outcome. Prostagland. Med. 5: 343-344 (1980).

Schou, M.: Problems of lithium prophylaxis: efficacy, serum lithium, selection of patients; in Christo-doulou, Aspects of preventive psychiatry. Biblthca psychiat., No. 160, pp. 30-37 (Karger, Basel 1981).

Schou, M.: Late side effects of lithium treatment; in Christodoulou, Aspects of preventive psychiatry. Biblthca psychiat., No. 160, pp. 45-48 (Karger, Basel 1981).

Schou, M.: Bibliography on the biology and pharmacology of lithium. 8. Neuropsychobiology 7:26-55 (1981).

Schou, M.; Amdisen, A.: Lithium. Side Eff. Drugs Annu. 5:22-27(1981).

Schou, M.; Mellerup, E.T.; Rafaelsen, O.J.: Mode of action of lithium; in van Praag, Lader, Rafaelsen, Sachar, Handbook of biological psychiatry, pp. 805-824 (Marcel Dekker, New York 1981). Schou, M.; Vestergaard, P.: Lithium and the kidney

276

Schou

scare. (Editorial.) Psychosomatics 22: 92-94 (1981).

Schou, M.; Vestergaard, P.: Lithium og nyreskræk: orientering og vurdering. (Lithium and kidney scare: information and evaluation.) Mskr. prakt. Lægegern. 58: 686-689 (1980).

Schou, M.; Weinstein, M.R.: Problems of lithium maintenance treatment during pregnancy, delivery and lactation. Agressologie 21: suppl. A, pp. 7-10 (1980).

Schwarcz, G.: Serum lithium spot checks for manic-depressive patients. Am. J. Psychiat. 137: 744-745 (1980)

Scotto di Telia, A.M.; Dessaigne, S.; Mercier, J.: Peut-on determiner expérimentalement les propriétés antidépressives du lithium? (Can we experimentally determine the antidepressive properties of lithium?) Encéphale 6: 115-129 (1980).

Sedgwick, J.B.; Bergstresser, P.R.; Hurd, E.R.: Increased granulocyte adherence in psoriasis and psoriatic arthritis. J. invest. Derm. 74: 81-84 (1980).

Sengupta, N.; Datta, S.C.; Sengupta, D.; Bal, S.: Platelet and erythrocyte-membrane adenosine triphos-phatase activity in depressive and manic-depressive illness. Psychiat. Res. 3: 337-344 (1980).

Serup, J.; Brun, C: Interaktion mellem litium og neu-roleptika. (Interaction between lithium and neuro-leptics.) Ugeskr. Læg. 142: $2643-2644$ (1980).

Shaffi, S.A.: Effect of lithium on hexokinase, Na, K-activated ATPase and nonspecific phosphomono-esterase in different regions of the adult rat brain. Ciênc, Cult., S Paulo 32: 63-69 (1980).

Shah, G.V.; Gunjikar, A.N.; Sheth, A.R.; Raut, S.J.: Effect of prolactin and spermine on the zinc content of human spermatozoa. Andrologia 12: 207-210(1980).

Shah, J.H.; Pishdad, G.: The effect of lithium on glucose- and tolbutamide-induced insulin release and glucose tolerance in the intact rat. Endocrinology 707: 1300-1304(1980).

Shaughnessy, R.; Dorus, E.; Pandey, G.N.; Davis, J.M.: Personality correlates of platelet monoamine oxidase activity and red cell lithium transport. Psychiat. Res. 2: 63-74 (1980).

Sheard, M.H.: The biological effects of lithium. Trends Neurosci. 3: 85-86 (1980).

Shenkman, L.; Borkowsky, W.; Holzman, R.S.; Shop-sin, B.: Lithium chloride, an in vitro immunologic adjuvant. Med. Hypotheses 6: 1-6 (1980).

Shimizu, ML: Relationship between blood lithium concentration and clinical effect. (In Japanese.) Jap. J. Neuropsychopharmacol. 2: 479^t86 (1980)

Shimizu, M.; Oana, Y.; Sakaue, N.; Ikeda, R.: Case report on Basedow psychosis improved by lithium carbonate. (In Japanese.) J. Tokyo med. Coll. $38: 445-447$ (1980).

Shimomura, K.; Sabo, Y.; Mori, J.: Characteristic hy-perpyrexia induced by lithium chloride and tranyl-cypromine in rats. Jap. J. Pharmac, 30: 268-271 (1980)

Shopsin, B.; Waters, B.: The pharmacotherapy of major depressive syndrome. 2. Prophylaxis of recurrent depressive illness. Psychosomatics 21: 649-651, 655-656(1980).

Siegel, J.N.; Johnston, R.B., Jr.; Lowe, R.S.; Epstein, P.S.; Rossof, A.H.: Effects of lithium on neutrophil metabolism in vitro and on neutrophil function during therapy; in Rossof, Robinson, Lithium effects on granulopoiesis and immune function, pp. 371-388 (Plenum, New York 1980).

Siggins, G.R.; Schultz, J.E.: Chronic treatment with lithium or desimipramine alters discharge frequency and norepinephrine responsiveness of cere-bellar Purkinje cells. Proc, natn. Acad. Sci. USA 76:5987-5991 (1979).

Sitnikova, R.V.; Krylova, A.N.: Comparison of photometric methods for the determination of lithium levels in biological fluids. (In Russian.) Lab. Delo 3: 142-145 (1980).

Skinner, G.R.B.; Hartley, C; Buchan, A.; Harper, L.; Gallimore, P.: The effect of lithium chloride on the replication of herpes simplex virus. Med. Micro-biol. Immunol. 168: 139-148 (1980).

Skinner, P.: Leucocytosis in lithium-treated outpatients. Br. J. Psychiat. 137: 104 (1980).

Skula, E.; Novotná, J.; Pfikryl, T.: Adherence to lithio-therapy. Activitas nerv. sup. 22: 176 (1980).

Slotkin, T.A.; Seidler, F.J.; Whitmore, W.L.; Salvag-gio, M.; Bareis, D.L.: Release of $\left[{ }^{3} \mathrm{H}\right]$ norepinephrine from synaptic vesicles isolated from rat brain after the intracisternal administration of $\left[{ }^{3} \mathrm{H}\right]$ norepinephrine: influence of nucleotides, ions and drugs, and destabilization of transmitter storage caused by acute or chronic lithium administration. Neuroscience 5: 753-762 (1980).

Small, J.G.; Kellams, J.J.; Milstein, V.; Small, I.F.: Complications with electroconvulsive treatment combined with lithium. Biol. Psychiat. 75: 103- 112(1980).

Small, J.G.; Kellams, J.J.; Milstein, V.; Small, I.F.: Complicaton
Bibliography on the Biology and Pharmacology of Lithium. 9 277

Smith, D.F.: Lithium and animal behavior, vol. 1 (Eden Press, Montreal 1977, Churchill Livingstone, Edinburgh 1977).

Smith, D.F.: Lithium and motor activity of animals. Effects and possible mechanisms of action; thesis Aarhus(1980).

Smith, D.F.: Central and peripheral effects of lithium on conditioned taste aversions in rats. Psychophar-macology 68: 315-317 (1980). 
Smith, D.F.: Lithium and animal behavior, vol. 2 (Eden Press, Montreal 1981, Churchill Livingstone, Edinburgh 1981).

Solomon, J.G.: Lithium toxicity precipitated by a diuretic. Psychosomatics 21: 425 (1980)

Sorensen, E.N.; Rosen, B.P.: Effects of sodium and lithium ions on the potassium ion transport systems of Escherichia coli. Biochemistry 19: 1458-1462 (1980).

Soucek, K.; Krulík, R.; Zatecká, I.: The efflux of lithium from red blood cells and the effects of lithium prophylaxis. Activitas nerv. sup. 21: 166-168 (1979)

Soucek, K.; Zvolský, P.: Lithium v roce 1978. (Lithium in 1978.) Clska Psychiat. 75: 363-368 (1979).

Squire, L.R.; Judd, L.L.; Janowsky, D.S.; Huey, L.Y.: Effects of lithium carbonate on memory and other cognitive functions. Am. J. Psychiat. 137: 1042-1046(1980). Srinivasan, D.P.; Hullin, R.P.: Current concepts of lithium therapy. Br. J. Hosp. Med. 24: $466 \wedge 75$ (1980).

Srinivasan, V.; Venkoba Rao, A.; Parvathi Devi, S.; Hariharasubramanian, N.: Serum magnesium and calcium in manic depressives on lithium. Indian J. Psychiat. 18: 305-312 (1976)

Stefano, G.B.; Catapane, E.J.; Aiello, E.; Hiripi, L.: The calcium-dependent neuronal release of serotonin and its antagonism by lithium. J. Neurobiol. 11: 179-192 (1980).

Stein, R.S.; Flexner, J.H.; Graber, S.E.: Lithium and granulocytopenia during induction therapy of acute myelogenous leukemia: update of an ongoing trial; in Rossof, Robinson, Lithium effects on gran-ulopoiesis and immune function, pp. 187-197 (Plenum, New York 1980).

Stein, R.S.; Howard, C.A.: Lithium therapy of chronic neutropenia; in Rossof, Robinson, Lithium effects on granulopoiesis and immune function, pp. 321-332 (Plenum, New York 1980).

Stein, Z.L.G.: Comments on lithium article. Drug Intell. clin. Pharmacy 14: 137-138 (1980).

Steinberg, D.: The use of lithium carbonate in adolescence. J. Child Psychol. Pychiat. 21: 263-271 (1980).

Steiner, M.; Haskett, R.F.; Osmun, J.N.; Carroll, B.J.; Treatment of premenstrual tension with lithium carbonate. Acta psychiat. scand. 61: 96-102 (1980).

Steinherz, P.G.; Rosen, G.; Ghavimi, F.; Wang, Y.; Miller, D.R.: The effect of lithium carbonate on leukopenia after chemotherapy. J. Pediat. 96: 923-926(1980).

Steinherz, P.G.; Rosen, G.; Ghavimi, F.; Wollner, N.; Wang, Y.; Miller, D.R.: Higher leukocyte nadirs with lithium carbonate after chemotherapy; in Rossof, Robinson, Lithium effects on granulopoiesis and immune function, pp. 231-243 (Plenum, New York 1980).

Stepke, F.L.; Harding, G.F.; Jenner, F.A.; Mora, J.D.: Studies of a changing laterality index in a patient treated with lithium; in Gruzelier, Flor-Henry, Hemisphere asymmetries of function in psychopa-thology, pp. 255-256 (Elsevier, Amsterdam 1979).

Stern, S.L.; Rush, A.J.; Mendels, J.: Toward a rational pharmacotherapy of depression. Am. J. Psychiat. 137: 545-552 (1980).

Stone, M.H.: Madness and the moon revisited. Psychiat. Ann. 6: 170-176 (1976).

Suh, K.Y.: Two cases of convulsions during lithium overdosage. Korean Central J. Med. 28: 289-292 (1975).

Süss, W.; Sälzer, J.; Kuntze, M.: Analogcomputerstu-dien zur Pharmakokinetik des Lithiums im menschlichen Organismus. (Analogcomputer studies on the pharmacokinetics of lithium in the human organism.) Süss, W.; Sälzer, J.; Kuntze, M.: Analogcomputerstu-dien zur Pharmakokinetik des Lithiums im menschlichen Organismus. (Analogcomputer studies on the pharmacokinetics of lithium in the human organism.)
Zentbl. Pharm. 779: 385-389 (1980). Süss, W.; Sälzer, J.; Kuntze, M.: Untersuchungen zur Bioverfligbarkeit und Erfassung von Nebenwir-kungen bei der Anwendung von Lithiumsalz-Ta-bletten mit verzögerter Wirkstoffliberation. (Bio-availability
and side effects during use of retard lithium tablets.) Zentbl. Pharm. 779: 391-394 (1980).

Suva, J.; Janoušek, I.; Kolomaznik, K.: Levels of mineral elements in the serum and saliva of healthy male volunteers after a single dose of $\mathrm{Li}_{2} \mathrm{CO}_{3}$. Activitas nerv. sup. 22: $177-178$ (1980).

Suva,
Schou

Suva, J.; Janousek, I.; Svejnohova, D.: Early lithium levels in rat serum, blood cells and some organs. Activitas nerv. sup. 22: 121-122 (1980).

Svejnohova, D.; Janousek, I.; Suva, J.: Study of lithium levels in the serum and genital organs of male rats. Activitas nerv. sup. 22: 178-180 (1980).

Švestka, J.: Therapy and prophylaxis of manic-depressive psychosis with lithium carbonate, with respect to possibility of prediction of the therapeutic results. Acta Fac, med. Univ. brun. 65: 25-101 (1979).

Swann, A.C.; Heninger, G.R.; Marini, J.L.; Sheard, M.H.; Maas, J.W.: Lithium effects on high-affinity tryptophan uptake: evidence against a stabilization mechanism. Brain Res. 194: 287-292 (1980).

Swann, A.C.; Marini, J.L.; Sheard, M.H.; Maas, J.W.: Effects of chronic dietary lithium on activity and regulation of (Na, K)-adenosine triphosphatase in rat brain. Biochem. Pharmac. 29: 2819-2824 (1980).

Szentistványi, I.; Janka, Z.; Rimanóczy, A.; Latzko-vits, L.; Juhász, A.: Comparison of lithium and sodium transports in primary cultures of dissociated brain cells. Cell. mol. Biol. 25: 315-321 (1979).

Szentistványi, I.; Janka, Z.; Szilárd, J.: Clinical significance of sodium-dependent lithium transport in affective psychoses. Psychiatria clin. 13: 57-64 (1980).

Takahashi, R.; Nakane, Y.; Akiyama, A.: Lithium treatment in affective disorders from viewpoint of transcultural psychopharmacology: therapeutic plasma level. Folia psychiat. neurol. jap. 33: 501-509(1979).

Takahashi, R.; Nakane, Y.; Akiyama, A.: Lithium treatment in affective disorders from viewpoint of transcultural psychopharmacology: ther
Takayama, M.: Lithium treatment and changes of the electroencephalogram. (In Japanese.) J. Tokyo Worn. med. Coll. 49: 545-553 (1979).

Tanaka, A.; Takatsu, A.: Electrocardiographic changes during lithium treatment. (In Japanese.) J. Tokyo Worn. med. Coll. 50: 543-550 (1980).

Tanimoto, K.; Maeda, K.; Yamaguchi, N.; Chihara, K.; Fujita, T.: Effect of lithium on prolactin response to thyrotropin releasing hormone in patients with manic state. Psychopharmacology 72: 129-133(1981).

Taylor, M.A.; Abrams, R.: Reassessing the bipolar-unipolar dichotomy. J. affect. Dịs. 2: 195-217 (1980).

Tegeler, J.: Manisch-depressive Kranke: Therapie und Prophylaxe mit Lithium-Salzen. (Patients with

manic-depressive illness: therapy and prophylaxis with lithium salts.) Monatskurse ärztl. Fortbild. 29:736-742 (1979).

Thams, P.; Geisler, A.: Dissociation by lithium of hormone-induced formation of cyclic AMP and release of glycerol in isolated rat fat cells. Acta pharmac. tox. 46:382-387(1980).

Thams, P.; Geisler, A.: Dissociation by lithium of hormone-induced formation of cyclic AMP and release of glycerol in isolated rat fat cells. Acta pharmac. tox. 46:382-387(1980).
Thellier, M.; Hartmann, A.; Lassalles, J.P.; Garrec, J.P.: A tracer method to study unidirectional fluxes of lithium: application to frog skin. Biochim. bio-phys. Acta 598: 339-344 (1980).

Thellier, M.; Heurtaux, C; Wissocq, J.-C: Quantitative study of the distribution of lithium in the mouse brain for various doses of lithium given to the animal. Brain. Res. 199: 175-196 (1980).

Thellier, M.; Wissocq, J.-C; Heurtaux, C: Quantitative microlocation of lithium in the brain by a (n, $\alpha$ ) nuclear reaction. Nature, Lond. 283: 299-302 (1980).

Thiels, C: Psychopharmaka und Schwangerschaft: eine Übersịcht. (Psychotropic drugs and pregnancy: a review.) Pharmakopsychiatr. Neuro-Psy-chopharmakol. 13: 301-317 (1980).

Thomsen, K.; Olesen, O.V.: Effect of anesthesia and surgery on urine flow and electrolyte excretion in different rat strains. Renal Physiol. (in press).

Thysell, H.; Brante, G.; Sjöstedt, L.; Lindergård, B.; Lindholm, T.; Franzen, G.; Rorsman, B.: Glome-rular filtration rate and calcium metabolism in long-term lithium treatment. Neuropsychobiology 7: 105-111 (1981).

Tisman, G.; Wu, S.J.G.: A seven-year laboratory and clinical experience with lithium carbonate as an adjuvant to cancer chemotherapy; in Rossof, Robinson, Lithium effects on granulopoiesis and immune function, pp. 257-274 (Plenum, New York 1980).

Treiser, S.; Kellar, K.J.: Lithium: effects on serotonin receptors in rat brain. Eur. J. Pharmacol. 64: 183-185 (1980).

Turner, A.R.; Allalunis, M.J.: Oral lithium carbonate increases colony stimulating activity production from human mononuclear cells; in Rossof, Robinson, Lithium effects on granulopoiesis and immune function, pp. 127-136 (Plenum, New York 1980).

Turner, A.R.; MacDonald, R.N.: A placebo controlled study of a seven-day course of lithium carbonate following myelotoxic chemotherapy; in Rossof, Robinson, Lithium effects on granulopoiesis and Bibliography on the Biology and Pharmacology of Lithium. 9 279

immune function, pp. 199-205 (Plenum, New York 1980).

Turner, A.R.; MacDonald, R.N.; McPherson, T.A.: Reduction of chemotherapy-induced neutropenic complications with a short course of lithium carbonate. Clin. invest. Med. 2: 51-54 (1979).

Tyrer, P.; Alexander, M.S.; Regan, A.; Lee, I.: An extrapyramidal syndrome after lithium therapy. Br. J. Psychiat. 136: 191-194 (1980).

Ullrich, A.; Baierl, P.; ten Bruggencate, G.: Extracellular potassium in rat cerebellar cortex during acute and chronic lithium application. Brain Res. 192: 287-290(1980).

Ullrich, I.H.: A review of lithium. W. Va. med. J. 76: 111-115 (1980).

Ulmar, G.; Degkwitz, R.: Lithium-Therapie und Schwangerschaft. (Lithium treatment and pregnancy.) Dt. Ärzteblatt 33: 2097 (1979).

Umbert, P.; Yafary, R.: Psoriasis recalcitrante durante el tratamiento con litium. (Resistant psoriasis during treatment with lithium.) Actas dermo-sifilográ-ficas 70:623-626(1979).

Vanna, M. de; Capus, L.: Gli effetti collaterali nel trat-tamento con sali di litio. (Side effects of treatment with lithium salts.) Minerva psichiat. 19: 69-75 (1978).

Vanna, M. de; Lorenzi, E.; Verrienti, P.: Anomalie elettroencefalografiche durante il trattamento con psicofarmaci. (EEG abnormalities during treatment with psychotropic drugs.) Minerva psichiat. 20:227236(1979).

Vaupel, H.A.; Labedzki, L.: Behavior of circulatory germ-cells under influence of lithium and dexa-methasone. Blut 41: 289-290 (1980). 
Vecchio, M. del; Famiglietti, L.A.; Maj, M.; Zizolfi, S.; Borriello, R.; Sciaudone, G.: Kinetics of lithium and rubidium after a single administration: blood and plasma levels during 24 hours in human volunteers. Acta neurol., Napoli 34: 204-213 (1979).

Velapoldi, R.A.; Paule, R.C.; Schaffer, R.; Mandel, J.; Machlan, L.A.; Garner, E.L.; Rains, T.C.: A reference method for the determination of lithium in serum. NBS Spec. Publ., US, pp. 260-269 (1980). Vendsborg, P.B.: Weight gain and body composition in lithium-treated rats. Acta pharmac, tox. 46: 373-381 (1980)

Verimer, T.; Goodale, D.B.; Long, J.P.; Flynn, J.R.: Lithium effects on haloperidol-induced pre- and postsynaptic dopamine receptor supersensitivity. J. Pharm. Pharmac. 32: 665-666 (1980).

Verma, D.D.; Spitzer, G.; Zander, A.R.; Beran, M.A.; Dicke, K.A.: Myelopoietic modulation by lithium: in vitro experiments on its mechanism of action in man; in Rossof, Robinson, Lithium effects on granulopoiesis and immune function, pp. 111-126 (Plenum, New York 1980)

Vestergaard, P.; Amdisen, A.: Lithium treatment and kidney function: a follow-up study of 237 patients in long-term treatment. Acta psychiat. scand. 63: 333-345 (1981).

Vestergaard, P.; Amdisen, A.; Hansen, H.E.; Schou, M.: Considerations récentes sur le traitement au lithium. S'agit-il d'une thérapeutique dangereuse pour le rein? (Recent developments in lithium treatment: is the kidney affection dangerous?) Encéphale 5: 633-639 (1979).

Vestergaard, P.; Amdisen, A.; Hansen, H.E.; Schou, M.: Recent developments in lithium treatment: is the kidney affection dangerous? in Mendlewicz, New advances in the diagnosis and treatment of depressive illness, pp. 155-162 (Excerpta Medica, Amsterdam 1980).

Vestergaard, P.; Amdisen, A.; Schou, M.: Clinically significant side effects of lithium treatment: a survey of 237 patients in long-term treatment. Acta psychiat. scand. 62: 193-200 (1980).

Vestergaard, P.; Hansen, H.E.: Assessment of renal concentrating ability in lithium-treated patients: comparison of long-term dehydration with administration of a vasopressin analogue. Acta psychiat. scand. 61 : $152-156(1980)$

Vestergaard, P.; Thomsen, K.: Renal side effects of lithium: the importance of the serum lithium level. Psychopharmacology 72: 203-204 (1981).

Visca, U.; Mensi, F.; Spina, M.P.; Bombara, R.; Giral-di, B.; Massari, A.; Rossi, F.; Santi, G.: Prevention by using lithium carbonate of neutropenia due to antiblastics; in Rossof, Robinson, Lithium effects on granulopoiesis and immune function, pp. 245-255 (Plenum, New York 1980).

Vogelzang, N.J.; Frenning, D.H.: Lithium and hema-topoiesis. New Engl. J. Med. 303: 525 (1980).

Wahlin, A.; Rapp, W.; Jonsson, E.H.: Failure of chlo-rothiazide to improve urinary concentrating capacity in lithium-treated patients. Acta med. scand. 207: 195-196(1980)

Walker, R.M.; Stoff, J.S.; Brown, R.S.; Epstein, F.H.: The relation of renal prostaglandịns to urinary dilution in lithium-induced nephrogenic diabetes innsipidus and normal subjects. Clin. Res. 28: 463 (1980).

280

Schou

Weiner, R.D.; Whanger, A.D.; Erwin, C.W.; Wilson, W.P.: Prolonged confusional state and EEG seizure activity following concurrent ECT and lithium use. Am. J. Psychiat. 137: 1452-1453 (1980)

Westbrook, R.F.; Hardy, W.T.; Faulks, I.: The effects of lithium upon drinking in the pigeon and rat. Physiol. Behav. 23: 861-865 (1979).

Wharton, R.N.: Accidental lithium carbonate treatment of thyrotoxicosis as mania. Am. J. Psychiat. 137: 747-748 (1980).

Willner, A.H.; Johnson, F.N.: The effects of lithium on the development of alcohol tolerance in Caras-sius Auratus. Int. J. Neurosci. 11: 125-130 (1980).

Winek, C.L.; Bricker, J.D.; Fuchtman, F.W.: Lithium intoxication: a case study. Forensic Sci. Int. 15: 227-231 (1980)

Wissocq, J.C.; Stelz, T.; Heurtaux, C; Bisconte, J.C.; Thellier, M.: Application of a (n, $\alpha$ ) nuclear reaction to the microlocalization of lithium in the mouse brain. J. Histochem. Cytochem. 27: 1462- 1470(1979).

Wood, K.; Coppen, A.: The effect of estrogens on plasma tryptophan and adrenergic function in patients treated with lithium; in Cooke, Estro-gen/progestogen in the management of the menopause, pp. 29-39 (University Park Press, Baltimore 1978).

Woolverton, W.L.; Balster, R.L.: The effects of lithium on choice between cocaine and food in the rhesus monkey. Commun. Psychopharmacol. 3: 309-318 (1979).

Yamada, K.; Furukawa, T.: Dopaminergic inhibition involved in the $\alpha$-naphtoxyacetic acid-induced jumping behavior in mice. Eur. J. Pharmacol. 63: 321-326(1980).

Yamaguchi, N.; Tanimoto, K.; Kuromaru, S.: Growth hormone release following thyrotropin-releasing hormone injection in manic patients receiving lithium carbonate. Psychoendocrinology 5: 253-259 (1980).

Yassa, R.; Ananth, J.; Mendis, T.: Lithium salts in leukopenic disorders. N.Y. State J. Med. 80:1076-1079(1980).

Yavorskii, A.N.; Samoilov, N.N.; Rychko, A.V.: Effect of lithium chloride on the neurosecretory system of the rat hypothalamus. Neurosci. behav. Physiol. 9:4O6-3/8O8(I979).

Young, G.A.R.: Lithium in haematology. Lancet $i i: 1249(1980)$

Zaldivar, R.: Geographical gradients of lithium concentrations in surface and drinking water and in plasma of exposed subjects. (In Spanish.) Revta méd. Chile 108: 822-824 (1980).

Zapletálek, M.; Kindernayová, H.; Groh, J.: Effect of lithium on potassium and calcium in serum, eryth-rocytes and in urine. Activitas nerv. sup. 22: 175-176(1980).

Ziche, M.; Maiorana, A.; Oka, T.; Gullino, P.M.: Influence of lithium on mammary tumor growth in vivo. Cancer Lett. 9: 219-224 (1980).

Zis, A.P.; Grof, P.; Webster, M.; Goodwin, F.K.: The cyclicity of affective disorders and its modifications by drugs. Psychopharmac, Bull. 16/4: 41-49 (1980)

Zor, U.; Strulovici, B.; Lamprecht, S.A.; Amsterdam, A.; Oplatka, A.; Lindner, H.R.: Effect of modulators of cytoskeletal function on desensitization and recovery of prostaglandin E-2 responsive ovarian adenylate cyclase. Prostaglandins 18: 869-882 (1979).

\section{Addendum}

After the submission of the manuscript a volume has turned up, which contains a number of articles dealing with lithium in relation to alcohol and alcoholism: Goodwin, D.W.; and Erickson, C.K. (eds.): Alcoholism and affective disorders: clinical, genetic, and biochemical studies (SP Med. Sci. Books, New York 1979). 